\title{
3 Research Square

\section{Development and Psychometric Testing of a Generic Student Engagement Scale for Contemporary Healthcare Education}

\section{Shuang Li}

Beijing Normal University

Simon Ching LAM ( $\nabla$ simlc@alumni.cuhk.net)

Hong Kong Polytechnic University https://orcid.org/0000-0002-2982-9192

\section{Summer Cho Nga Siu}

Open University of Hong Kong

Jessie Yuk Seng Chung

Open university of Hong Kong

\section{Hemio Chung Yan Lam}

Open University of Hong Kong

\section{Eva Yuen Mei Tsang}

Open University of Hong Kong

\section{Kam Cheong Li}

Open University of Hong Kong

\section{Research article}

Keywords: nursing education, validation studies, psychometric, factor analysis

Posted Date: July 29th, 2020

DOl: https://doi.org/10.21203/rs.3.rs-45483/v1

License: (1) This work is licensed under a Creative Commons Attribution 4.0 International License. Read Full License 


\section{Abstract}

Background: Student engagement receives heightened research attention in traditional and contemporary education. This study aimed to develop and validate a Generic Student Engagement Scale (GSES) for the use in contemporary healthcare education including online, distance learning or e-learning.

Methods:

A 2-phased methodological study employed a cross-sectional design with repeated measures. Phase 1 aimed to develop the items of GSES for the use in generic learning environment of nursing students through item development/revision, content validation, face validation, and statement standardization. Phase 2 aimed to test the psychometric properties of the newly developed GSES on its internal consistency, stability, and factorial validity. Data was collected in 2016-2018.

Results:

Based on 45 items of the Distance Students Engagement Scale (i.e., 3-factor model), 39 items were revised and adapted to fit the generic learning environment in nursing education. Seven experts and 20 nursing students examined each items and indicated a satisfactory content (CVI $=0.71-1.00$ except item G9) and face validity ( $100 \%$ comprehensibility and interpretability). By analyzing 451 valid data from nursing students, confirmatory factor analysis did not support this 3-factor model GSES. Exploratory factor analysis was used to explore the new internal structure of GSES. The 26-item 4-factor solution that accounted for a total of $41.0 \%$ variance was found the most optimal. The factors were labelled "self-regulated learning", "cognitive strategy use", "teacher-student interaction", and "experienced emotion". The internal consistency and stability of this new model was re-examined with satisfactory results.

Conclusions:

The newly developed 26-item 4-factor GSES is reliable and valid scale measuring student engagement among nursing students.

\section{Background}

Embracing contemporary education, like online, distance learning or e-learning, has become a strategic choice for colleges and universities in respond to the increasingly flexible, personalized learning needs or more applicability to the specific circumstances (e.g., the COVID-19 pandemic). Online teaching can better meet the needs of personalized learning, respond faster and easier to adjust the teaching materials according to the realistic working environment [1]. Furthermore, regarding the healthcare disciplines, online teaching provides more flexible and open for healthcare education to carry out practical skills training and problem-solving ability training based on work current scenarios. Hence, it has been favored by medical schools or healthcare educational institutions recently [2]. In 2020, the COVID-19 pandemics forced the implementation of new measures of infection control and prevention including social distancing and stay home but has effectively promoted the integration of online education and various traditional education model [3]. Because of that, online teaching required technologies and equipment has been greatly advanced 
[2]. Since online learning is more dependent on students' autonomy and self-regulated, student engagement in the online mode of learning would be a concern for all educators [4].

\section{Student Engagement}

Student engagement is defined by Kuh as the time and energy students devote to educationally sound activities,which is regarded as a key factor that facilitates school completion, enhances achievement motivation [5], and associated with student's academic performance [6]. From the educational and institutional perspectives, student engagement is considered an important factor that leads to educational reform and evaluation, and that mediated the influence of curricular and instructional reforms on student achievement [7]. Student engagement has gained greater importance in the field of higher education because higher education highlights the independence, autonomy, and freedom in learning [8]. Both Kuh [9] and Coates [10] consistently suggested that student engagement should be regarded as an indicator of higher education institutional performance by inducing students to participate in educationally purposeful activities. With the advent of online education, an increasing number of higher education institutions have emphasized the importance of promoting online student engagement thus to improve student achievement in the online environment, and as a way to address the boredom and dropout problems of online learning $[11,12]$. Consequently, the measurement of online student engagement has gradually become a focus of higher education research, particularly in healthcare disciplines that is commonly regarded as bachelor level or higher diploma as fundamental entrance.

\section{Measurement of Student Engagement}

There were several existing scales measuring student engagement in the literature [13]; however, these rarely reflect the increased technology and online use in both teaching and learning. The multifaceted nature of engagement has already been reflected and documented in the education literature over the last few decades. However, the constructs of engagement vary with both the theoretical perspective of the researcher and the educational context in which the student engages himself/herself [14]. Recently, with the advancement of technological innovations in education, the learning environment has shifted from the classroom to a hybrid learning environment that blends both Web and face-to-face components in the same course. The hybrid learning environment such as the integration of e-learning [15], mobile learning [16], and simulation [17] is also common in nursing education. More importantly, online learning would be sole mode and new trend to keep the education of healthcare disciplines during the period of pandemics [11].

Fredricks and Paris [18] proposed and tested a three-dimensional construct of engagement that appropriately covers the most essential elements and encompasses "behavioral engagement, emotional engagement, and cognitive engagement" (p. 62), which is a more recognized engagement in the literature [14]. Behavioral engagement represents student behaviors while being involved in school activities (including following the rules) and academic tasks. Emotional engagement refers to "students' affective reactions" (p. 63) both inside the classroom and in the school campus in general. Cognitive engagement is described as a preference for challenge, strategy use, and self-regulation. The three-dimensional construct of student engagement is widely accepted in the literature because it was adequately encompassed the key 
dimensions on reflecting student engagement and applicable to any kind of teaching modes including traditional classroom teaching and online education.

For these new initiatives, many traditional instruments are now considered inadequate in capturing student engagement under the new learning environment, thus requiring the development of new engagement models and their corresponding instruments. However,literature review shows that there is limited reliable and valid scale to unfold student engagement in the online learning environment. A scale named as Online Student Engagement (OSE) Scale revised from Handelsman et al.'s Student Course Engagement Questionnaire [6] was claimed to fit for measurement of engagement in online environment [11]. This 19itme scale measures engagement in four engagement factors including skills, emotion, participation and performance. However, both the theoretical framework and how the items were constructed are still questionable. For example, the adequacy of the scale might be skeptical because cognitive aspect mentioned by the three-dimensional construct of engagement is missed. Moreover, incorporating the learning outcomes ("performance" factor of OSE) as items (i.e., item 15: Getting a good grade, item 16: Doing well on the quizzes) for reflecting students engagement was controversial and invited many criticism [18]. More importantly, this scale was generic for the use but not specific developed for measuring the student engagement in online learning environment.

Distance Student Engagement Scale (DSES) was developed based on three-dimensional construct of engagement [18] to measure student engagement for students enrolled in universities and online educational institutions in China [19]. Unlike other instruments measuring engagement using the traditional learning methods, DSES contains items that reflect the use of contemporary technologies in the blended learning mode, such as online platforms, discussion forums, audiovisual materials, and so on. The blended learning perspective of DSES largely matches the situation of Hong Kong higher education relevant to any international universities.

DSES is a 45-item self-administrated questionnaire presented in simplified Chinese [the written version of Chinese used in Hong Kong and Taiwan] [20]. A three-factor structure (behavioral, emotional and cognitive engagement) has been identified using exploratory factor analysis. The behavioral engagement subscale measures students' involvement in learning related to activities such as active participation and sharing, whereas the emotional engagement subscale measures students' emotional input in states such as happiness, curiosity and boredom. The cognitive engagement subscale reflects students' mental affordance such as elaboration and metacognition. The psychometric properties of DSES including internal consistency, criterion-related validity, and construct validity (assessed by confirmatory factor analysis) are all satisfactory (e.g., Cronbach's alpha $=0.88-0.96$ for the scale and subscales; Comparative Fit Index $=$ 0.81 , Tucker-Lewis Index $=0.80$, Root Mean Square Error of Approximation < 0.08 ) (details referred to [19]).

Fredricks and McColskey [13] emphasized that students from different socioeconomic status and educational contexts may require distinct items and instruments that can accurately reflect their engagement. Even though the psychometric properties of DSES have been examined in a group of healthcare students in mainland China, the process of cross-cultural adaptation and retesting the psychometric properties are still necessary when DSES are applied to different target groups in cultures. To 
carefully examine the applicability of this scale to the contemporary healthcare education in Hong Kong, the current study aimed to revise and translate (into English) the DSES for adapting to measure the student engagement in the online higher education. Furthermore, the psychometric properties of the revised DSES were examined among a group of students in healthcare disciplines.

\section{Methods}

\section{Study Design}

This was a methodological study employing cross-sectional design. The process employed a recognized instrument development design that consists of two phases, namely item generation and psychometric testing $[21,22]$. Table 1 presents the overview of the study plan. Data of two phases was collected in 20162018.

Table 1

a. Phase 1 study: Development of Generic Student Engagement Scale (OSES)

\begin{tabular}{|c|c|c|}
\hline Steps & Aims & Methods \\
\hline $\begin{array}{l}\text { Step 1: } \\
\text { Development of } \\
\text { items }\end{array}$ & $\begin{array}{l}\text { To develop the items by } \\
\text { modifying the items of DSES } \\
\text { and to rename the instrument } \\
\text { as GSES }\end{array}$ & $\begin{array}{l}\text { Examination of each DSES items and adapting } \\
\text { them into generic learning environment of both } \\
\text { full-time and distance learning student by research } \\
\text { team }\end{array}$ \\
\hline $\begin{array}{l}\text { Step 2: Content } \\
\text { validation }\end{array}$ & $\begin{array}{l}\text { To examine the relevance of } \\
\text { each OSES item }\end{array}$ & Examination by a panel of seven experts \\
\hline $\begin{array}{l}\text { Step 3: Face } \\
\text { validation }\end{array}$ & $\begin{array}{l}\text { To examine the } \\
\text { comprehensibility \& } \\
\text { interpretability of each GSES } \\
\text { item }\end{array}$ & $\begin{array}{l}\text { Examination by a group of target respondents (i.e., } \\
20 \text { students studying in healthcare disciplines) }\end{array}$ \\
\hline $\begin{array}{l}\text { Step 4: } \\
\text { Standardization } \\
\text { of item } \\
\text { statement }\end{array}$ & $\begin{array}{l}\text { To standardize the item by the } \\
\text { use of consistent tone, } \\
\text { statement pattern, phrases, } \\
\text { etc. }\end{array}$ & $\begin{array}{l}\text { Standardization of the entire OSES by the research } \\
\text { team }\end{array}$ \\
\hline
\end{tabular}


Table 1

b. Phase 2 study: Psychometric testing of Generic Student Engagement Scale (GSES)

\begin{tabular}{|lll|}
\hline $\begin{array}{l}\text { Psychometric } \\
\text { properties }\end{array}$ & Methods of testing & Statistical methods \\
\hline Reliability & Cronbach's alpha method & $\begin{array}{l}\text { Cronbach's alpha } \\
\text { statistics }\end{array}$ \\
\hline $\begin{array}{l}\text { Internal } \\
\text { consistency }\end{array}$ & 4-week test-retest reliability & $\begin{array}{l}\text { Intraclass correlation } \\
\text { coefficient (ICC) }\end{array}$ \\
\hline Stability & $\begin{array}{l}\text { Factorial validation: inspecting the theoretical } \\
\text { components of the construct }\end{array}$ & $\begin{array}{l}\text { Confirmatory factor } \\
\text { analysis (CFA) }\end{array}$ \\
\hline $\begin{array}{l}\text { Construct } \\
\text { validity }\end{array}$ & & \\
\hline
\end{tabular}

In Phase 1, the study aimed to adapt the items of DSES to reflect the student engagement of a generic and contemporary learning environment using a 4-step approach. In step 1, the research team examined each DSES item and check whether it is comprehensible in Cantonese, the local dialect of Hong Kong (both English and Chinese), appropriate to reflect engagement under common online learning environments relevant to students studying in full-time, blended learning or distance learning modes. All items that were in simplified Chinese were verbatim revised to traditional Chinese [the written version commonly used in Hong Kong] and translated English afterwards. The statement for instruction was added to make it specific to online learning experience. The revised DSES would be renamed to Generic Student Engagement Scale (GSES) to better refer its nature. Step 2 was to perform content validation. A panel of seven experts was invited to examine relevance and adequacy of the first draft of GSES. Step 3 was to perform face validation. A group of 20 target respondents (i.e., 20 randomly selected students studying in higher education) was invited to comment on the comprehensibility and interpretability of the drafted GSES items, where such method is suggested in the literature $[22,23,29]$. Step 4 was the standardization of item statement. Items were rephrased in a uniform manner and similar sentence structure to facilitate the respondents' comprehensibility. The major principles observed in item construction are maintenance of clarity, preference for short statements, avoidance of double negatives, avoidance of double-barreled statements, and avoidance of factual statements according to the typical method in designing item [22, 23, 24].

Phase 2 aimed to perform psychometric testing of the newly developed GSES in measuring the student engagement among a group of nursing students studying in higher education. Reliability of GSES was reflected through its internal consistency and stability. For construct validity, confirmatory factor analysis (CFA) was used to evaluate whether a pre-specified factor model of GSES provides a good fit to the data [25]. This method that examined the internal structure of target instrument provided evidence to the construct validity.

\section{Setting and Sample}

Phase 1 involved a panel of at least seven experts (including educators working in higher education and researchers with experience in education or social science) and 20 randomly selected students studying in 
higher education.

In Phase 2, a convenient sample consists of about 650 full-time students who were major in healthcare subjects (e.g., nursing, dietitian, physiotherapist) were recruited. They were studying in a local University in Hong Kong. Based on Li \& Yu [19], a 30\% attrition rate was estimated. As Li \& Yu [19] conducted CFA using a sample size of 443 , this study invited 650 participants to ensure a comparable sample size. Then, a subsetsample of 70 participants was selected to respond to the GSES four weeks later for examining the test-retest reliability [26].

\section{Ethical consideration}

The study obtained the approval from the ethical committee of the University. Through an information sheet given to them, all participants were fully informed about the aim and procedure of this study. The researchers explained and highlighted anonymity and confidentiality. It was estimated that the respondents spent about 20 minutes to complete the questionnaire.

\section{Measurement}

The questionnaire used in Phase 2 consisted of two parts. Part one was demographic questions including gender, age, and year of study. Part two was the GSES.

\section{Data Collection}

Prior to data collection, the study obtained the ethical approval from the ethical committee of the University. Through an information sheet given to them, all participants were fully informed about the aim and procedure of this study. The researchers explained and highlighted anonymity and confidentiality. It was estimated that the respondents spent about 20 minutes to complete the questionnaire.

\section{Data Analysis}

IBM ${ }^{\circledR}$ SPSS Statistics version 22 was used to analyze the quantitative data. Descriptive statistics, for example, frequency, percentage and mean were used to describe and summarize the questionnaire data. Inferential statistics including Cronbach's alpha and intraclass correlation coefficient were used to examine the internal consistency and stability, respectively. For confirmatory factor analysis, IBM® SPSS AMOS was used to test the hypothesized factor model of GSES.

Both the Descriptive statistics and inferential statistics were adopted to conduct psychometric testing as follows. Significant level is set at 0.05 .

\section{Content validation}

Seven experts were invited to evaluate the relevancy of the items using a 4-point Likert scale (i.e., $1=$ not relevant; 2 = somewhat relevant; 3 = quite relevant; 4 = highly relevant) and adequacy of the entire scale on a dichotomy scale (i.e., yes/no). For the problematic items receiving a rating of 2 or below, written comments were required. Experts were asked to suggest additional item if there was a query of inadequacy. The content validity index (CVI) included item-level CVI (i.e., proportion of content that experts gave the item a relevance rating of 3 or 4 ) and scale-level CVI (i.e., average of the Item-CVIs for all items on the scale) were 
both computed and presented. The indices above were used to indicate the proportion of relevant responses. According to Polit, Beck and Owen [27] and Portney and Watkins [28], when using an expert panel of six members, the criterion level needed for item-level CVI and scale-level CVI should be greater than or equal to 0.80 to indicate the validity of instrument content.

\section{Face validation}

Twenty students from several healthcare courses were invited to evaluate the instrument "for assuring the expression of the items was understandable words and style" [29]. The participants inspected and commented on each item to attain comprehensibility (i.e., Yes/No nominal scale), and rephrased each item based on their own words (i.e., the interpretability). For that, the researchers determined whether the rephrased content was appropriate on 4-point scale (i.e., 1 = fully correct, 2 = general correct; 3 partially wrong; 4 = totally wrong) [28]. The participants would ask to make suggestion through discussion if there was a great discrepancy (i.e., score $=3$ or 4 ) in the interpretation.

\section{Internal consistency}

The Cronbach's alpha was calculated to determine the captioned property. The internal consistency should be considered adequate if the value was greater than 0.7 of the parameter indicates [28].

\section{Stability}

Through four-week test-retest reliability, the initial scores of the GSES with the ones obtained from the same participants four weeks later were compared. An Intraclass Correlation Coefficient (ICC) greater than 0.75 would indicate good test-retest reliability [28].

\section{Construct validation}

The internal structure of GSES was tested by CFA, which is regarded as the most rigorous method to do so [28]. It examined the degree of fitness of the data in a hypothesized model. Correlation matrices were entered in the analyses and the maximum likelihood estimation procedure in AMOS software was used to conduct each analysis. The goodness-of-fit measures that were used to assess model fit included: the Chisquare/degree of freedom ratio $\left(\chi^{2} /\right.$ d.f.), the root mean square error of approximation (RMSEA), the comparative fit index $(\mathrm{CFI})$, and the incremental fit index (IFI). All of them were frequently reported indices $[21,28]$. The goodness-of-fit criteria for the indices were $\chi^{2} /$ d.f. $<3.00, \mathrm{CFI}$ and IFI $>0.90$, and RMSEA $<0.08$ [30]. If CFA failed to validate the internal structure of GSES, exploratory factor analysis (EFA) should be used to explore the new factor structure of student engagement among the nursing student in Hong Kong higher education [28].

\section{Results}

Out of the 45 items of DSES, 39 items were reworded and contextualized into a generic learning environment in higher education to different extents. Many items were revised or rephrased to increase the comprehensibility due to the language change from the written language commonly used in Beijing to one commonly used in Hong Kong. For examples, "would" in the original version $(n=30)$ was deleted because 
this instrument aimed to reflect the student engagement through their actual learning experiences but not their expectations. Some items (i.e., item D6,D12,D16,D17,D18,D30,D31,D32,D33,D34,D35,D38) were revised to remove the emphasis on the distance learning mode. Examples of various learning materials, devices and platforms were appropriately added in blanket to increase the relevance and adaptability of the GSES for fitting into different learning modes (i.e., item D1,D2,D11,D24,D28,D29). A few items (i.e., item $\mathrm{D} 24, \mathrm{D} 27, \mathrm{D} 31, \mathrm{D} 33, \mathrm{D} 34)$ were shortened to increase clarify of the items.

In step 2, seven experts, including academic staff in nursing and social science, commented on the relevance and adequacy of 45 -item GSES. The Item-level CVI ranged from 0.80 to 1.00, except item G9 with 0.43 , and some items $(\mathrm{G} 12, \mathrm{G} 17, \mathrm{G} 23, \mathrm{G} 28, \mathrm{G} 34, \mathrm{G} 46)$ with 0.71 . Regarding the item $\mathrm{G} 9$ "discussion of nonacademic related matters with teachers and students", the experts wondered why the discourse of "nonacademic matters" should be relevant to the engagement scale. This item was used to reflect the construct "behavioral engagement" through assessing their habits of sharing daily matters with someone in school. Like the National Survey of Student Engagement (NSSE, http://nsse.indiana.edu/), some items assessed the engagement in student life including "activities other than coursework", "management of non-academic responsibilities", and "attending campus activities and events" [6]. Therefore, item G9 was retained. The items with Item-level CVI of 0.71 were considered good because of the increase in the number of experts [27]. In general, the Scale-level CVI was 0.92 .

In step 3, twenty students studying a bachelor degree or a higher diploma in healthcare courses reviewed and commented on the comprehensibility and interpretability of 45 -item GSES. They indicated whether they could comprehend each item first and then they were requested to describe and explain each item in their own words. The result indicated all items were $100 \%$ comprehensibility and interpretability.

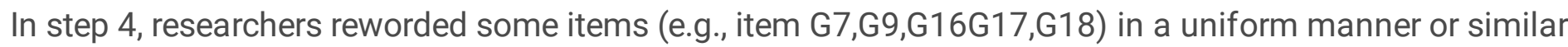
sentence structure. For example, the term "teachers or students" is consistently used to refer "people who come into contact during the learning process in school". Table 2 presents the overall description of item modification and justifications behind for the abovementioned steps.

For the study in phase 2, a total of 665 students from different healthcare courses participated in the study. After the data cleansing procedure, 214 data sets (attrition rate $=32.1 \%$ ) were removed because of habitual responses and incomplete data, leaving 451 data sets for analysis (i.e., 163 studying higher diploma year 1 , 91 studying higher diploma year 2, 112 studying bachelor degree year 1, 91 studying bachelor degree year 2). Their age ranged from 18 to 33 -year-old (mean $=20.6)$. Female $(n=348)$ accounted for $77.2 \%$ of total participants.

The GSES demonstrated a satisfactory reliability. The score of Cronbach's alpha, reflecting the internal consistency of the scale, were 0.93 . Those of subscales were $0.80,0.84$ and 0.90 for behavioral, emotional and cognitive engagement subscales respectively. For the stability, the 4-week test retest on 70 randomly selected subsamples indicated that the ICC was 0.88 (95\% confidence interval $=0.81-0.92$ ), which suggested an evidence of good stability. 
Face, content and construct validation of GSES were all performed. The results of face and content validation have been presented in the phase 1 study. For construct validation, the results of CFA were unsatisfactory. CFA did not support the hypothesized 3-factor structure of GSES with unacceptable goodness of fit index (i.e., $\chi^{2} / \mathrm{df}(3793.80 / 942)=4.03, \mathrm{CFI}=0.64$, ILI $=0.65$, RMSEA $\left.=0.08\right)$. Table 3 illustrates the psychometric properties of the GSES in comparisons with DSES. As the fit statistics did not support the three-factor model of GSES in students of healthcare disciplines, the EFA was, then, used to explore any new structure of the GSES. First, the suitability of data for factor analysis was assessed using Bartlett's test of sphericity and the Kaiser-Meyer-Olkin (KMO) measure of sampling adequacy [31]. Bartlett's test of sphericity that reached statistical significance (Chi-squared $=18693.51, d f=990, p<.001$ ) and the $\mathrm{KMO}$ value of $0.89(\geq 0.60)$ was considered to support the factorability of the correlation matrix [31]. Based on the results of Kaiser's criterion and Scree plot test, the research examined the item loadings on 2, 3, 4 and 5 factor models by various extraction methods (i.e., principal component analysis for general use, maximum likelihood for normally-distributed data or principle axis factoring for non-normally-distributed data) with two rotation methods (i.e., promax for oblique rotation or varimax for orthogonal method) [32]. A total of 24 factor solutions were computed, examined and compared. Eventually, the 26 -item 4 -factor solution, as shown in Table 4, was identified to be the most optimal by principal component analysis with varimax rotation because of maintaining conceptual adequacy and less crossloadings [32]. Indeed, the internal structure of this version was most interpretable and clear, with items measuring similar dimensions of engagement clustered together in similar way as suggested by the literature [18, 29]. This 4 -factor structure accounts for a total of $41.02 \%$ of variance. The factors were then labelled as: "self-regulated learning" (factor 1,9 items, $26.42 \%$ of variance) which refers to a learning cognition that is regulated proactively by oneself; "cognitive strategy use" (factor 2, 6 items, $5.59 \%$ of variance) which refers to learning strategies effectively used by oneself; "teacher-student interaction" (factor 3, 6 items, $4.88 \%$ of variance) which refers to one's learning behavior through interaction with teachers and students; and "experienced emotion" (factor 4,6 items, $4.13 \%$ of variance) which refers to typical emotions experienced through the process of learning. 
Table 3

Reliability and validity of the 26-item GSES with comparisons of 45-item DSES ( $N=451)$.

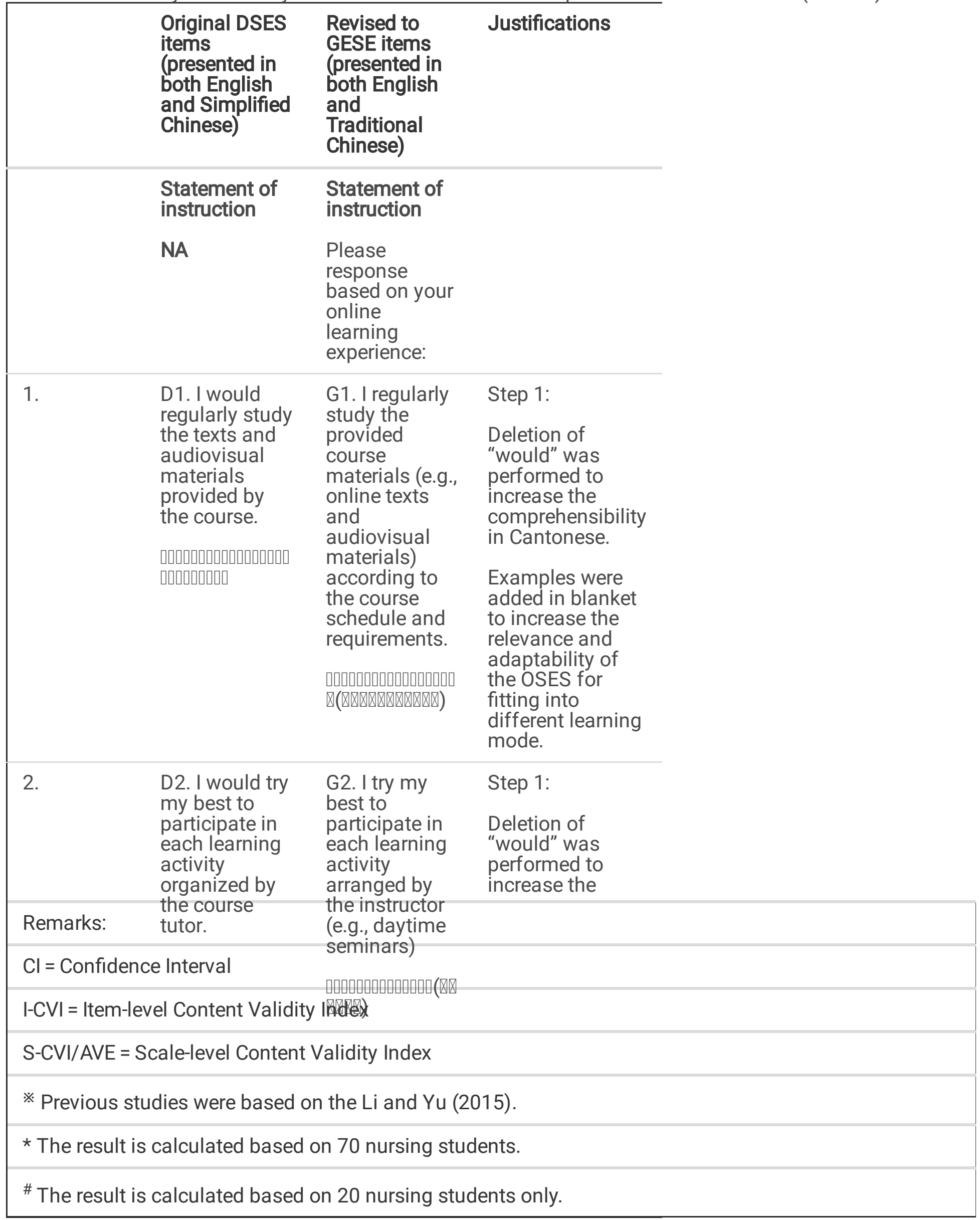




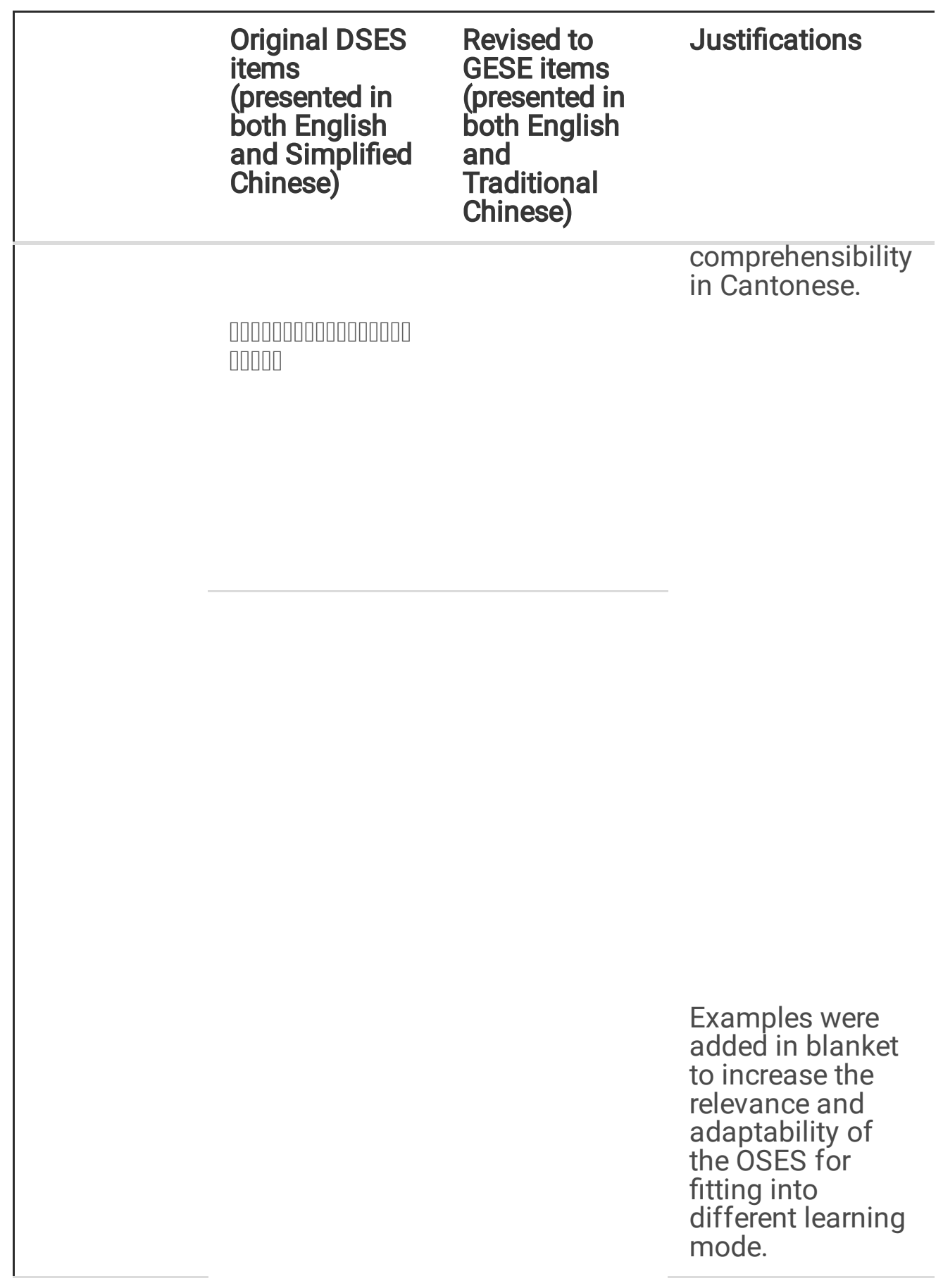

\section{Remarks:}

$\mathrm{Cl}=$ Confidence Interval

$\mathrm{I}-\mathrm{CVI}=$ Item-level Content Validity Index

S-CVI/AVE = Scale-level Content Validity Index

* Previous studies were based on the Li and Yu (2015).

* The result is calculated based on 70 nursing students.

\# The result is calculated based on 20 nursing students only. 


\begin{tabular}{|c|c|c|c|}
\hline & $\begin{array}{l}\text { Original DSES } \\
\text { items } \\
\text { (presented in } \\
\text { both English } \\
\text { and Simplified } \\
\text { Chinese) }\end{array}$ & $\begin{array}{l}\text { Revised to } \\
\text { GESE items } \\
\text { (presented in } \\
\text { both English } \\
\text { and } \\
\text { Traditional } \\
\text { Chinese) }\end{array}$ & Justifications \\
\hline \multirow[t]{2}{*}{3.} & $\begin{array}{l}\text { D3. I would } \\
\text { reserve } \\
\text { enough time to } \\
\text { complete the } \\
\text { course } \\
\text { learning tasks. }\end{array}$ & $\begin{array}{l}\text { G3. I reserve } \\
\text { enough time } \\
\text { to complete } \\
\text { the course } \\
\text { learning tasks. } \\
\text {. }\end{array}$ & $\begin{array}{l}\text { Step 1: } \\
\text { Deletion of } \\
\text { "would" was } \\
\text { performed to } \\
\text { increase the } \\
\text { comprehensibility } \\
\text { in Cantonese. }\end{array}$ \\
\hline & 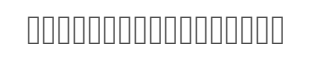 & & \\
\hline \multicolumn{4}{|c|}{ Remarks: } \\
\hline \multicolumn{4}{|c|}{$\mathrm{Cl}=$ Confidence Interval } \\
\hline \multicolumn{4}{|c|}{ I-CVI = Item-level Content Validity Index } \\
\hline \multicolumn{4}{|c|}{ S-CVI/AVE = Scale-level Content Validity Index } \\
\hline \multicolumn{4}{|c|}{ * Previous studies were based on the Li and Yu (2015). } \\
\hline \multicolumn{4}{|c|}{ * The result is calculated based on 70 nursing students. } \\
\hline
\end{tabular}




\begin{tabular}{|c|c|c|c|}
\hline & $\begin{array}{l}\text { Original DSES } \\
\text { items } \\
\text { (presented in } \\
\text { both English } \\
\text { and Simplified } \\
\text { Chinese) }\end{array}$ & $\begin{array}{l}\text { Revised to } \\
\text { GESE items } \\
\text { (presented in } \\
\text { both English } \\
\text { and } \\
\text { Traditional } \\
\text { Chinese) }\end{array}$ & Justifications \\
\hline 4. & 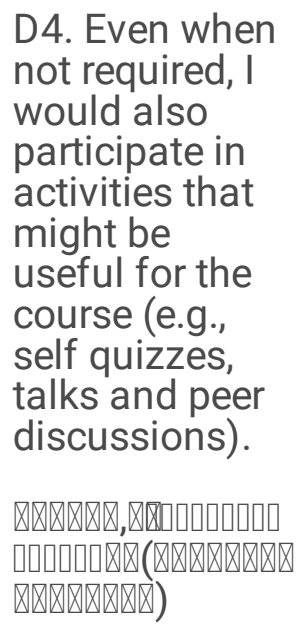 & 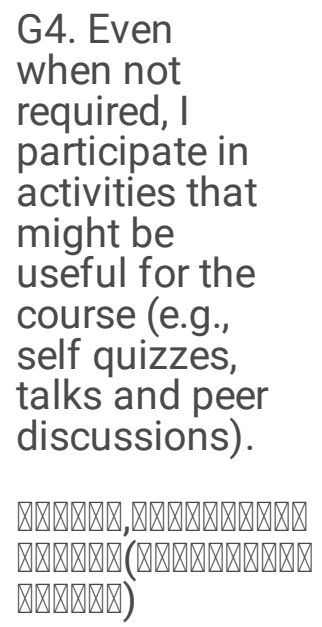 & $\begin{array}{l}\text { Step 1: } \\
\text { Deletion of } \\
\text { "would" was } \\
\text { performed to } \\
\text { increase the } \\
\text { comprehensibility } \\
\text { in Cantonese. }\end{array}$ \\
\hline
\end{tabular}

\section{Remarks:}

$\mathrm{Cl}=$ Confidence Interval

$\mathrm{I}-\mathrm{CVI}=$ Item-level Content Validity Index

S-CVI/AVE = Scale-level Content Validity Index

* Previous studies were based on the Li and Yu (2015).

* The result is calculated based on 70 nursing students.

\# The result is calculated based on 20 nursing students only. 


\begin{tabular}{|c|c|c|c|}
\hline & $\begin{array}{l}\text { Original DSES } \\
\text { items } \\
\text { (presented in } \\
\text { both English } \\
\text { and Simplified } \\
\text { Chinese) }\end{array}$ & $\begin{array}{l}\text { Revised to } \\
\text { GESE items } \\
\text { (presented in } \\
\text { both English } \\
\text { and } \\
\text { Traditional } \\
\text { Chinese) }\end{array}$ & Justifications \\
\hline 5. & 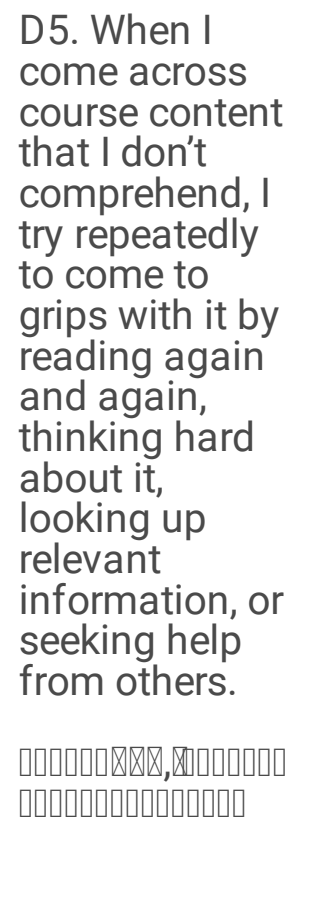 & 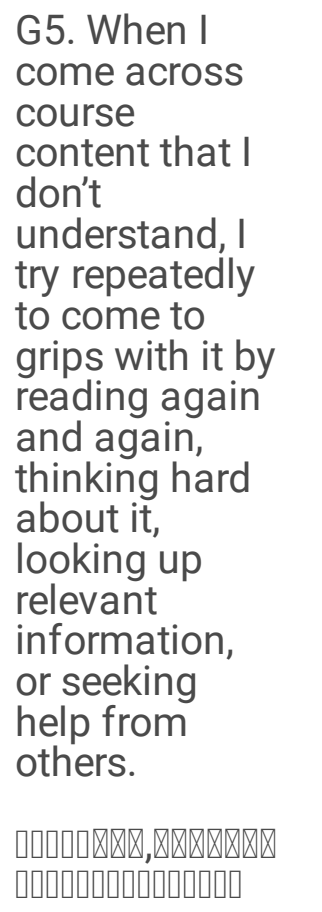 & $\begin{array}{l}\text { Step 1: } \\
\text { The use of } \\
\text { "understand" can } \\
\text { increase the } \\
\text { comprehensibility } \\
\text { in Cantonese. }\end{array}$ \\
\hline 6. & 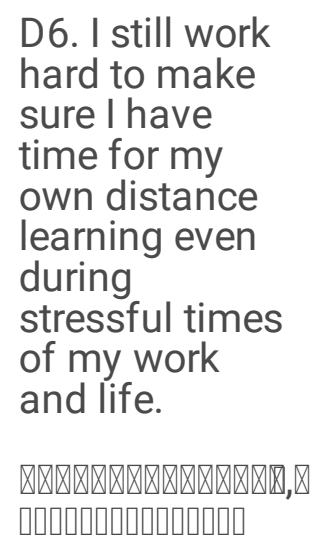 & 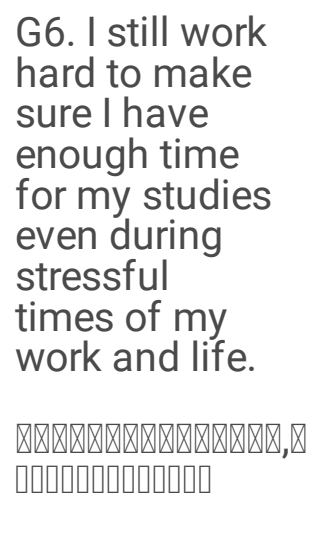 & $\begin{array}{l}\text { Step 1: } \\
\text { The emphasis of } \\
\text { distance learning } \\
\text { mode was } \\
\text { removed. }\end{array}$ \\
\hline
\end{tabular}

\section{Remarks:}

$\mathrm{Cl}=$ Confidence Interval

$\mathrm{I}-\mathrm{CVI}=$ Item-level Content Validity Index

S-CVI/AVE = Scale-level Content Validity Index

※ Previous studies were based on the Li and Yu (2015).

* The result is calculated based on 70 nursing students.

\# The result is calculated based on 20 nursing students only. 


\begin{tabular}{|c|c|c|c|}
\hline & $\begin{array}{l}\text { Original DSES } \\
\text { items } \\
\text { (presented in } \\
\text { both English } \\
\text { and Simplified } \\
\text { Chinese) }\end{array}$ & $\begin{array}{l}\text { Revised to } \\
\text { GESE items } \\
\text { (presented in } \\
\text { both English } \\
\text { and } \\
\text { Traditional } \\
\text { Chinese) }\end{array}$ & Justifications \\
\hline 7. & 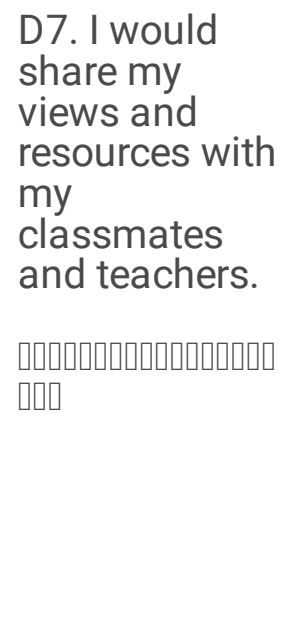 & 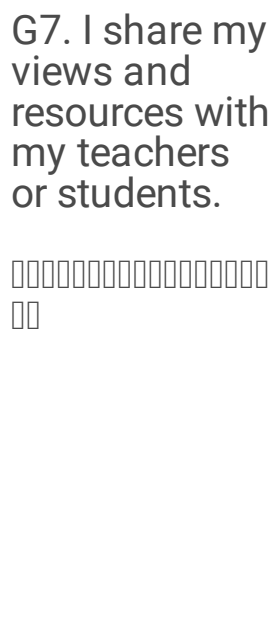 & $\begin{array}{l}\text { Step 1: } \\
\text { Deletion of } \\
\text { "would" was } \\
\text { performed to } \\
\text { increase the } \\
\text { comprehensibility } \\
\text { in Cantonese. } \\
\text { Step 4: } \\
\text { Standardization } \\
\text { of the use of } \\
\text { "teachers or } \\
\text { students" }\end{array}$ \\
\hline 8. & 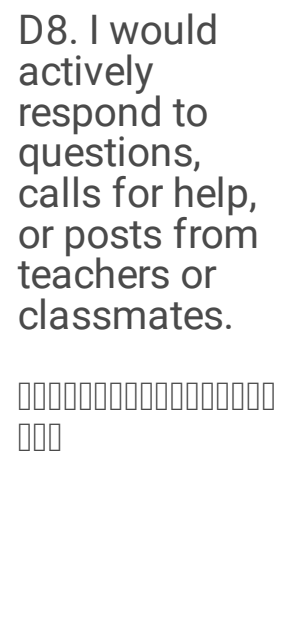 & 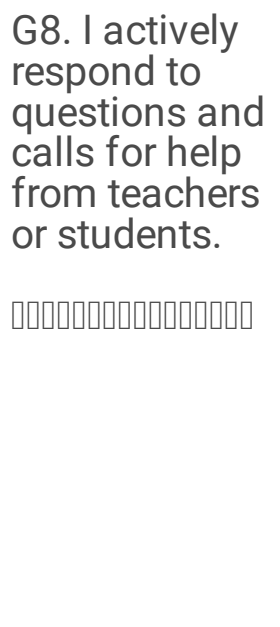 & $\begin{array}{l}\text { Step 1: } \\
\text { Deletion of } \\
\text { "would" was } \\
\text { performed to } \\
\text { increase the } \\
\text { comprehensibility } \\
\text { in Cantonese. } \\
\text { Step 4: } \\
\text { Standardization } \\
\text { of the use of } \\
\text { "teachers or } \\
\text { students" }\end{array}$ \\
\hline
\end{tabular}

\section{Remarks:}

$\mathrm{Cl}=$ Confidence Interval

$\mathrm{I}-\mathrm{CVI}=$ Item-level Content Validity Index

S-CVI/AVE = Scale-level Content Validity Index

※ Previous studies were based on the Li and Yu (2015).

* The result is calculated based on 70 nursing students.

\# The result is calculated based on 20 nursing students only. 


\begin{tabular}{|c|c|c|c|}
\hline & $\begin{array}{l}\text { Original DSES } \\
\text { items } \\
\text { (presented in } \\
\text { both English } \\
\text { and Simplified } \\
\text { Chinese) }\end{array}$ & $\begin{array}{l}\text { Revised to } \\
\text { GESE items } \\
\text { (presented in } \\
\text { both English } \\
\text { and } \\
\text { Traditional } \\
\text { Chinese) }\end{array}$ & Justifications \\
\hline 9. & 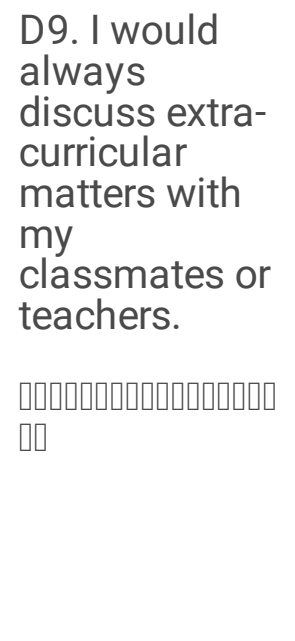 & 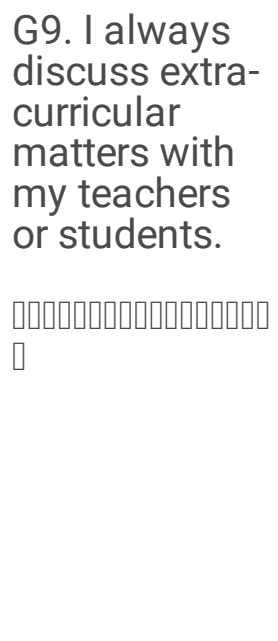 & $\begin{array}{l}\text { Step 1: } \\
\text { Deletion of } \\
\text { "would" was } \\
\text { performed to } \\
\text { increase the } \\
\text { comprehensibility } \\
\text { in Cantonese. } \\
\text { Step 4: } \\
\text { Standardization } \\
\text { of the use of } \\
\text { "teachers or } \\
\text { students" }\end{array}$ \\
\hline 10. & 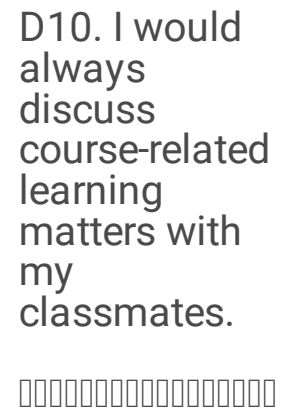 & 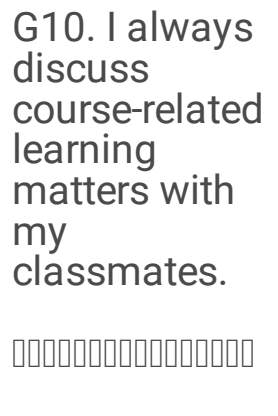 & $\begin{array}{l}\text { Step 1: } \\
\text { Deletion of } \\
\text { "would" was } \\
\text { performed to } \\
\text { increase the } \\
\text { comprehensibility } \\
\text { in Cantonese. }\end{array}$ \\
\hline
\end{tabular}

\section{Remarks:}

$\mathrm{Cl}=$ Confidence Interval

$\mathrm{I}-\mathrm{CVI}=$ Item-level Content Validity Index

S-CVI/AVE = Scale-level Content Validity Index

* Previous studies were based on the Li and Yu (2015).

* The result is calculated based on 70 nursing students.

\# The result is calculated based on 20 nursing students only. 


\begin{tabular}{|c|c|c|c|}
\hline & $\begin{array}{l}\text { Original DSES } \\
\text { items } \\
\text { (presented in } \\
\text { both English } \\
\text { and Simplified } \\
\text { Chinese) }\end{array}$ & $\begin{array}{l}\text { Revised to } \\
\text { GESE items } \\
\text { (presented in } \\
\text { both English } \\
\text { and } \\
\text { Traditional } \\
\text { Chinese) }\end{array}$ & Justifications \\
\hline 11. & 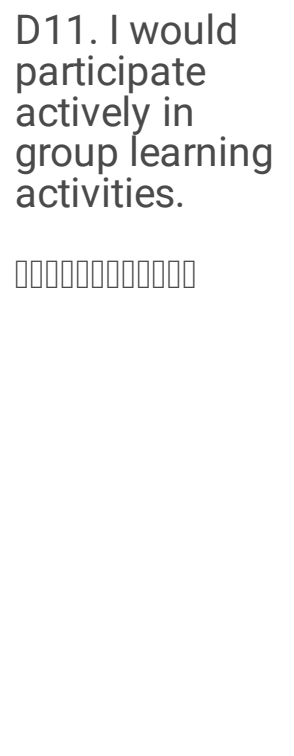 & 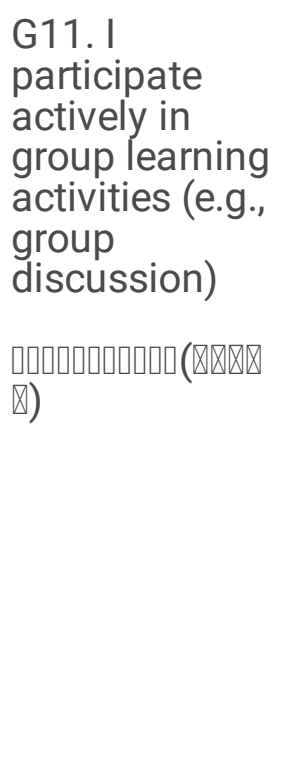 & $\begin{array}{l}\text { Step 1: } \\
\text { Deletion of } \\
\text { "would" was } \\
\text { performed to } \\
\text { increase the } \\
\text { comprehensibility } \\
\text { in Cantonese. } \\
\text { Examples were } \\
\text { added in blanket } \\
\text { to increase the } \\
\text { relevance and } \\
\text { adaptability of } \\
\text { the OSES for } \\
\text { fitting into } \\
\text { different learning } \\
\text { mode. }\end{array}$ \\
\hline 12. & 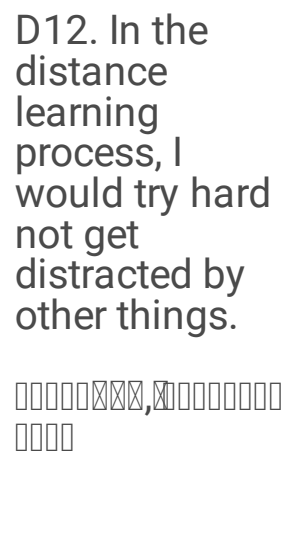 & $\begin{array}{l}\text { G12. In the } \\
\text { learning } \\
\text { process, I try } \\
\text { hard not get } \\
\text { distracted by } \\
\text { other things. } \\
\text { of } \\
\text { o }\end{array}$ & $\begin{array}{l}\text { Step 1: } \\
\text { Deletion of } \\
\text { "would" was } \\
\text { performed to } \\
\text { increase the } \\
\text { comprehensibility } \\
\text { in Cantonese. } \\
\text { The emphasis of } \\
\text { distance learning } \\
\text { mode was } \\
\text { removed. }\end{array}$ \\
\hline
\end{tabular}

\section{Remarks:}

$\mathrm{Cl}=$ Confidence Interval

$\mathrm{I}-\mathrm{CVI}=$ Item-level Content Validity Index

S-CVI/AVE = Scale-level Content Validity Index

* Previous studies were based on the Li and Yu (2015).

* The result is calculated based on 70 nursing students.

\# The result is calculated based on 20 nursing students only. 


\begin{tabular}{|c|c|c|c|}
\hline & $\begin{array}{l}\text { Original DSES } \\
\text { items } \\
\text { (presented in } \\
\text { both English } \\
\text { and Simplified } \\
\text { Chinese) }\end{array}$ & $\begin{array}{l}\text { Revised to } \\
\text { GESE items } \\
\text { (presented in } \\
\text { both English } \\
\text { and } \\
\text { Traditional } \\
\text { Chinese) }\end{array}$ & Justifications \\
\hline 13. & 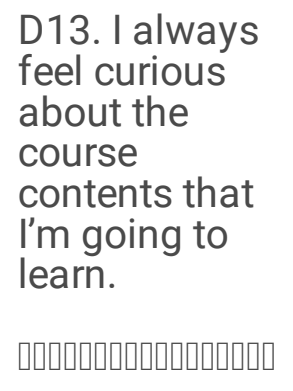 & 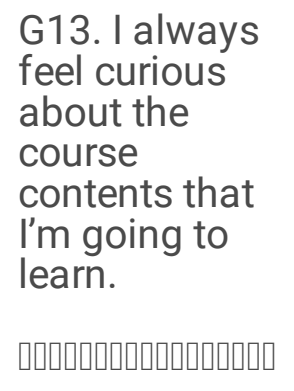 & I \\
\hline 14. & 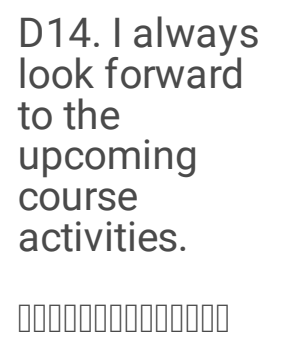 & 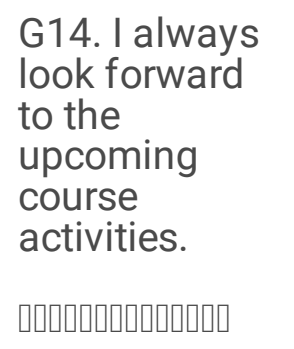 & I \\
\hline 15. & 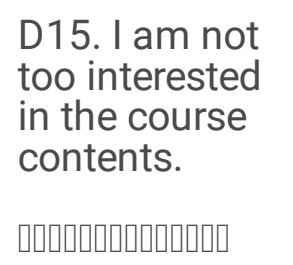 & $\begin{array}{l}\text { G15. I am not } \\
\text { too interested } \\
\text { in the course } \\
\text { contents. } \\
\end{array}$ & I \\
\hline
\end{tabular}

Remarks:

$\mathrm{Cl}=$ Confidence Interval

$\mathrm{I}-\mathrm{CVI}=$ Item-level Content Validity Index

S-CVI/AVE = Scale-level Content Validity Index

* Previous studies were based on the Li and Yu (2015).

* The result is calculated based on 70 nursing students.

\# The result is calculated based on 20 nursing students only. 


\begin{tabular}{|c|c|c|c|}
\hline & $\begin{array}{l}\text { Original DSES } \\
\text { items } \\
\text { (presented in } \\
\text { both English } \\
\text { and Simplified } \\
\text { Chinese) }\end{array}$ & $\begin{array}{l}\text { Revised to } \\
\text { GESE items } \\
\text { (presented in } \\
\text { both English } \\
\text { and } \\
\text { Traditional } \\
\text { Chinese) }\end{array}$ & Justifications \\
\hline 16. & 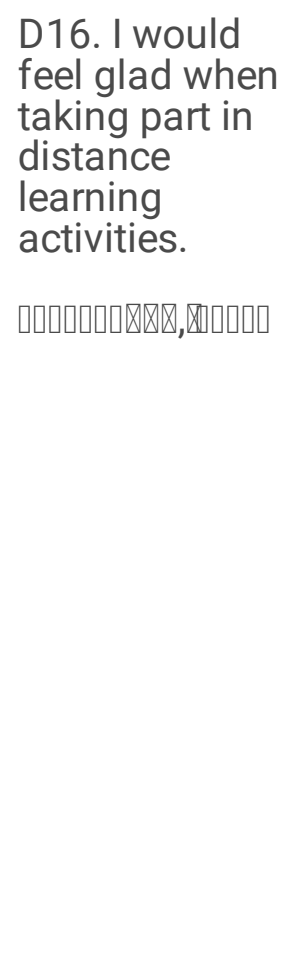 & $\begin{array}{l}\text { G16. I feel } \\
\text { happy when } \\
\text { taking part in } \\
\text { learning } \\
\text { activities. } \\
\\
\text { and }\end{array}$ & $\begin{array}{l}\text { Step 1: } \\
\text { Deletion of } \\
\text { "would" was } \\
\text { performed to } \\
\text { increase the } \\
\text { comprehensibility } \\
\text { in Cantonese. } \\
\text { The emphasis of } \\
\text { distance learning } \\
\text { mode was } \\
\text { removed. } \\
\text { Step 4: } \\
\text { Standardization } \\
\text { of the use of } \\
\text { adjective "happy" } \\
\text { to indicate the } \\
\text { positive feeling } \\
\text { of joy, gladness } \\
\text { and pleasure. }\end{array}$ \\
\hline 17. & 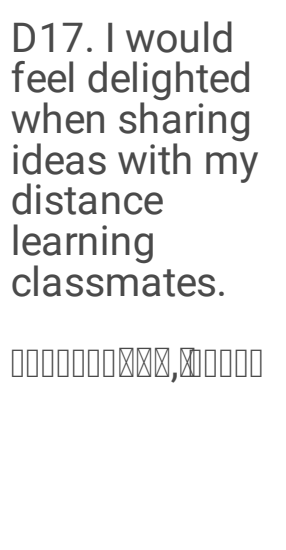 & $\begin{array}{l}\text { G17. I feel } \\
\text { happy when } \\
\text { sharing ideas } \\
\text { with my } \\
\text { classmates. } \\
\text { and }\end{array}$ & $\begin{array}{l}\text { Step 1: } \\
\text { Deletion of } \\
\text { "would" was } \\
\text { performed to } \\
\text { increase the } \\
\text { comprehensibility } \\
\text { in Cantonese. } \\
\text { The emphasis of } \\
\text { distance learning } \\
\text { mode was } \\
\text { removed. }\end{array}$ \\
\hline \multicolumn{4}{|c|}{ Remarks: } \\
\hline \multicolumn{4}{|c|}{$\mathrm{Cl}=$ Confidence Interval } \\
\hline \multicolumn{4}{|c|}{ I-CVI = Item-level Content Validity Index } \\
\hline \multicolumn{4}{|c|}{ S-CVI/AVE = Scale-level Content Validity Index } \\
\hline \multicolumn{4}{|c|}{ * Previous studies were based on the Li and Yu (2015). } \\
\hline \multicolumn{4}{|c|}{ * The result is calculated based on 70 nursing students. } \\
\hline
\end{tabular}




\begin{tabular}{llll}
\hline $\begin{array}{l}\text { Original DSES } \\
\text { items }\end{array}$ & $\begin{array}{l}\text { Revised to } \\
\text { (presented in } \\
\text { both English } \\
\text { and Simplified } \\
\text { Chinese) }\end{array}$ & $\begin{array}{l}\text { (presented in } \\
\text { both English } \\
\text { and }\end{array}$ \\
& $\begin{array}{l}\text { Traditional } \\
\text { Chinese) }\end{array}$
\end{tabular}

Step 4:

Standardization of the use of adjective "happy" to indicate the positive feeling of joy, gladness and pleasure.

18.

D18. I would feel happy when I finish the distance learning

Remarks: assignments.

G18. I feel happy when I finish course assignments.
Step 1:

Deletion of

"would" was

$\mathrm{Cl}=$ Confidence Interval,

$\mathrm{I}-\mathrm{CVI}=$ Item-level Content Validity Index

S-CVI/AVE = Scale-level Content Validity Index

* Previous studies were based on the Li and Yu (2015).

* The result is calculated based on 70 nursing students.

\# The result is calculated based on 20 nursing students only. 


\begin{tabular}{|lll}
\hline Original DSES & Revised to & Justifications \\
items & GESE items \\
(presented in & (presented in \\
both English & both English \\
and Simplified & and \\
Chinese) & $\begin{array}{l}\text { Traditional } \\
\text { Chinese) }\end{array}$
\end{tabular}

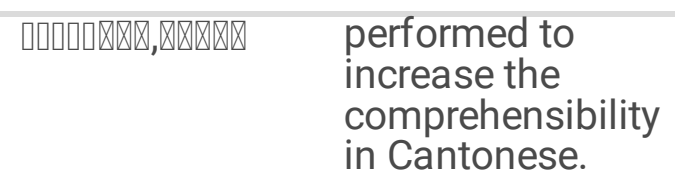

The emphasis of distance learning mode was removed.

Step 4:

Standardization of the use of adjective "happy"

Remarks:

$\mathrm{Cl}=$ Confidence Interval

$\mathrm{I}-\mathrm{CVI}=$ Item-level Content Validity Index

S-CVI/AVE = Scale-level Content Validity Index

* Previous studies were based on the Li and Yu (2015).

* The result is calculated based on 70 nursing students.

\# The result is calculated based on 20 nursing students only. 


\begin{tabular}{|c|c|c|c|}
\hline & $\begin{array}{l}\text { Original DSES } \\
\text { items } \\
\text { (presented in } \\
\text { both English } \\
\text { and Simplified } \\
\text { Chinese) }\end{array}$ & $\begin{array}{l}\text { Revised to } \\
\text { GESE items } \\
\text { (presented in } \\
\text { both English } \\
\text { and } \\
\text { Traditional } \\
\text { Chinese) }\end{array}$ & Justifications \\
\hline & & & $\begin{array}{l}\text { to indicate the } \\
\text { positive feeling } \\
\text { of joy, gladness } \\
\text { and pleasure. }\end{array}$ \\
\hline 19. & 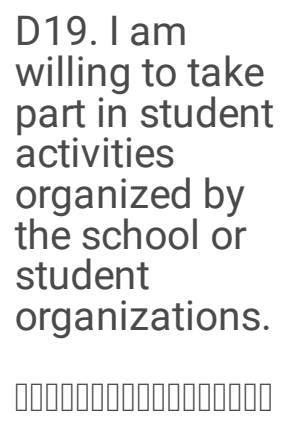 & 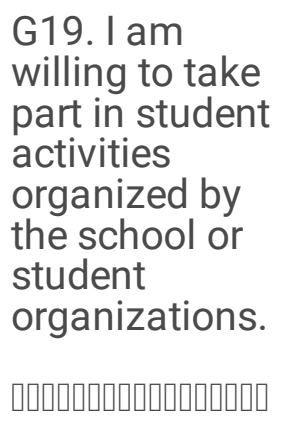 & / \\
\hline 20. & 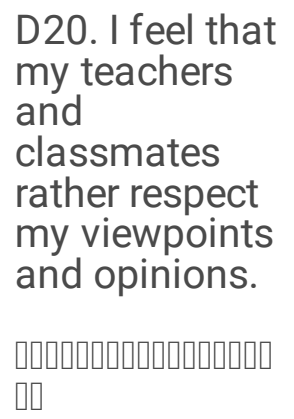 & 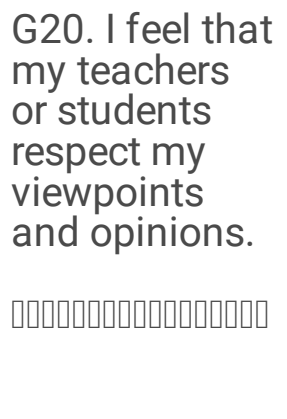 & $\begin{array}{l}\text { Step 4: } \\
\text { Standardization } \\
\text { of the use of } \\
\text { "teachers or } \\
\text { students" }\end{array}$ \\
\hline
\end{tabular}

\section{Remarks:}

$\mathrm{Cl}=$ Confidence Interval

$\mathrm{I}-\mathrm{CVI}=$ Item-level Content Validity Index

S-CVI/AVE = Scale-level Content Validity Index

* Previous studies were based on the Li and Yu (2015).

* The result is calculated based on 70 nursing students.

\# The result is calculated based on 20 nursing students only. 


\begin{tabular}{|c|c|c|c|}
\hline & $\begin{array}{l}\text { Original DSES } \\
\text { items } \\
\text { (presented in } \\
\text { both English } \\
\text { and Simplified } \\
\text { Chinese) }\end{array}$ & $\begin{array}{l}\text { Revised to } \\
\text { GESE items } \\
\text { (presented in } \\
\text { both English } \\
\text { and } \\
\text { Traditional } \\
\text { Chinese) }\end{array}$ & Justifications \\
\hline \multirow[t]{2}{*}{21.} & $\begin{array}{l}\text { D21. When } \\
\text { facing } \\
\text { difficulties, I } \\
\text { can always } \\
\text { feel the care } \\
\text { and concern } \\
\text { from my } \\
\text { teachers and } \\
\text { classmates. }\end{array}$ & $\begin{array}{l}\text { G21. When } \\
\text { facing } \\
\text { difficulties, I } \\
\text { can always } \\
\text { feel the care } \\
\text { and concern } \\
\text { from my } \\
\text { teachers or } \\
\text { students. }\end{array}$ & $\begin{array}{l}\text { Step 4: } \\
\text { Standardization } \\
\text { of the use of } \\
\text { "teachers or } \\
\text { students" }\end{array}$ \\
\hline & 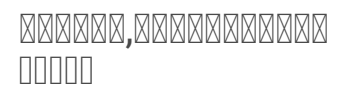 & 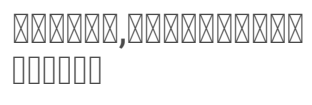 & \\
\hline \multirow[t]{2}{*}{22.} & $\begin{array}{l}\text { D22. I think I } \\
\text { have the } \\
\text { responsibility } \\
\text { to help my } \\
\text { classmates. }\end{array}$ & $\begin{array}{l}\text { G22. I think I } \\
\text { have the } \\
\text { responsibility } \\
\text { to help my } \\
\text { classmates. }\end{array}$ & / \\
\hline & 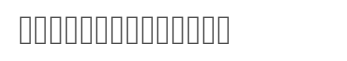 & 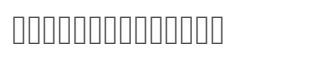 & \\
\hline \multirow[t]{2}{*}{23.} & $\begin{array}{l}\text { D23. I always } \\
\text { feel bored by } \\
\text { the course } \\
\text { contents } \\
\text { during the } \\
\text { learning } \\
\text { process. }\end{array}$ & $\begin{array}{l}\text { G23. I always } \\
\text { feel bored by } \\
\text { the course } \\
\text { contents } \\
\text { during the } \\
\text { learning } \\
\text { process. }\end{array}$ & / \\
\hline & 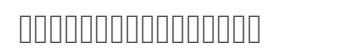 & 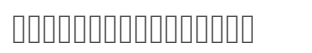 & \\
\hline
\end{tabular}

\section{Remarks:}

$\mathrm{Cl}=$ Confidence Interval

$\mathrm{I}-\mathrm{CVI}=$ Item-level Content Validity Index

S-CVI/AVE = Scale-level Content Validity Index

* Previous studies were based on the Li and Yu (2015).

* The result is calculated based on 70 nursing students.

\# The result is calculated based on 20 nursing students only. 


\begin{tabular}{|c|c|c|c|}
\hline & $\begin{array}{l}\text { Original DSES } \\
\text { items } \\
\text { (presented in } \\
\text { both English } \\
\text { and Simplified } \\
\text { Chinese) }\end{array}$ & $\begin{array}{l}\text { Revised to } \\
\text { GESE items } \\
\text { (presented in } \\
\text { both English } \\
\text { and } \\
\text { Traditional } \\
\text { Chinese) }\end{array}$ & Justifications \\
\hline 24. & 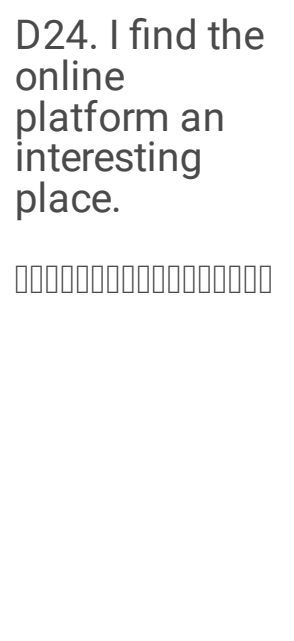 & $\begin{array}{l}\text { G24. I like } \\
\text { learning } \\
\text { through online } \\
\text { platforms } \\
\text { (e.g., Online } \\
\text { Learning } \\
\text { Environment) } \\
\\
\text { Oc|c|c|c|c| (ष } \\
\text { Online } \\
\text { Learning } \\
\text { Environment) }\end{array}$ & $\begin{array}{l}\text { Step 1: } \\
\text { Examples were } \\
\text { added in blanket } \\
\text { to increase the } \\
\text { relevance and } \\
\text { adaptability of } \\
\text { the OSES for } \\
\text { fitting into } \\
\text { different learning } \\
\text { mode. } \\
\text { Item was } \\
\text { shortened to } \\
\text { increase clarity. }\end{array}$ \\
\hline 25. & 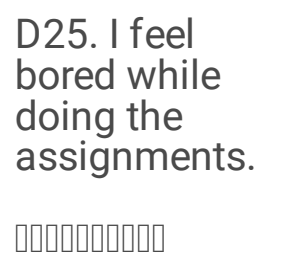 & 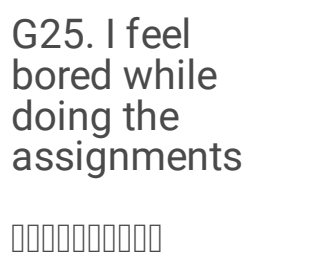 & $\begin{array}{l}\text { Step 1: } \\
\text { Item was revised } \\
\text { due to the } \\
\text { different Chinese } \\
\text { dialects. }\end{array}$ \\
\hline 26. & 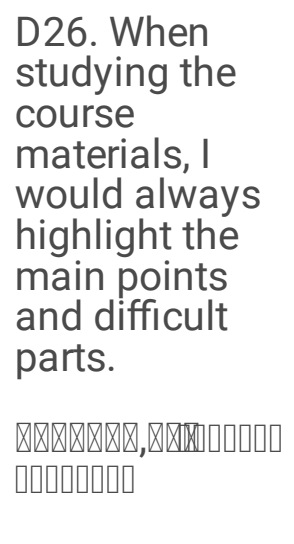 & 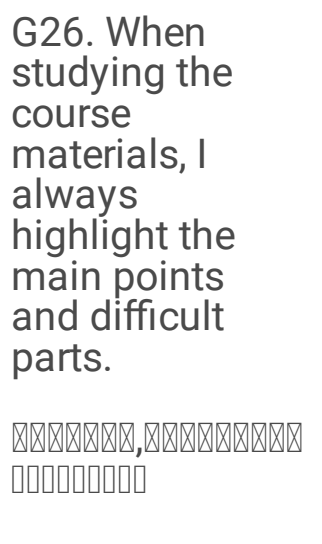 & $\begin{array}{l}\text { Step 1: } \\
\text { Deletion of } \\
\text { "would" was } \\
\text { performed to } \\
\text { increase the } \\
\text { comprehensibility } \\
\text { in Cantonese. } \\
\text { Item was revised } \\
\text { due to the } \\
\text { different Chinese } \\
\text { dialects. }\end{array}$ \\
\hline
\end{tabular}

\section{Remarks:}

$\mathrm{Cl}=$ Confidence Interval

$\mathrm{I}-\mathrm{CVI}=$ Item-level Content Validity Index

S-CVI/AVE = Scale-level Content Validity Index

* Previous studies were based on the Li and Yu (2015).

* The result is calculated based on 70 nursing students.

\# The result is calculated based on 20 nursing students only. 


\begin{tabular}{|c|c|c|c|}
\hline & $\begin{array}{l}\text { Original DSES } \\
\text { items } \\
\text { (presented in } \\
\text { both English } \\
\text { and Simplified } \\
\text { Chinese) }\end{array}$ & $\begin{array}{l}\text { Revised to } \\
\text { GESE items } \\
\text { (presented in } \\
\text { both English } \\
\text { and } \\
\text { Traditional } \\
\text { Chinese) }\end{array}$ & Justifications \\
\hline 27. & 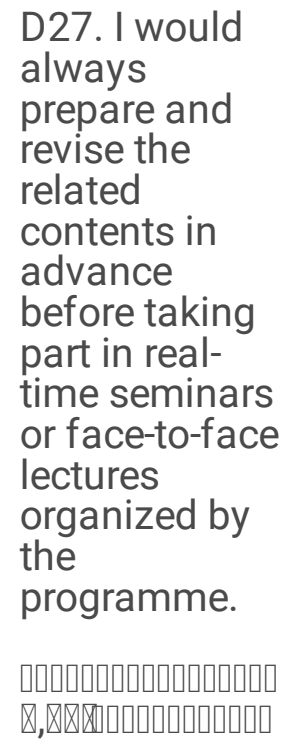 & $\begin{array}{l}\text { G27. I always } \\
\text { prepare and } \\
\text { revise the } \\
\text { related } \\
\text { contents in } \\
\text { advance } \\
\text { before } \\
\text { attending } \\
\text { lessons. } \\
\\
\text { a } \\
\end{array}$ & $\begin{array}{l}\text { Step 1: } \\
\text { Deletion of } \\
\text { "would" was } \\
\text { performed to } \\
\text { increase the } \\
\text { comprehensibility } \\
\text { in Cantonese. } \\
\text { Item was } \\
\text { shortened to } \\
\text { increase clarity. }\end{array}$ \\
\hline 28. & 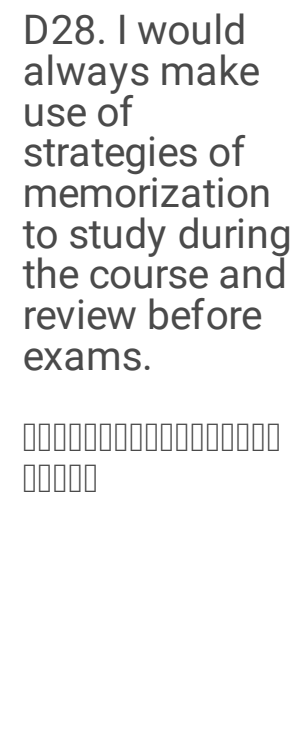 & 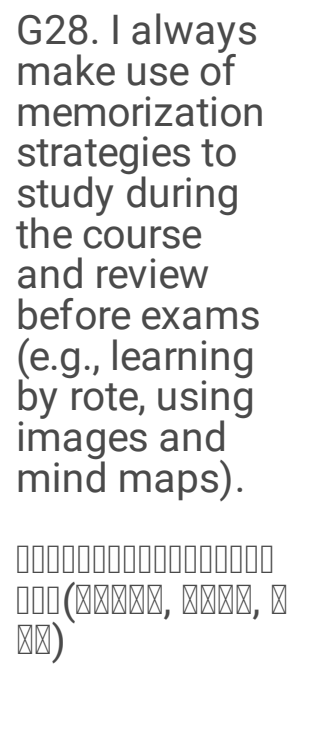 & $\begin{array}{l}\text { Step 1: } \\
\text { Deletion of } \\
\text { "would" was } \\
\text { performed to } \\
\text { increase the } \\
\text { comprehensibility } \\
\text { in Cantonese. } \\
\text { Examples were } \\
\text { added in blanket } \\
\text { to increase the } \\
\text { relevance and } \\
\text { adaptability of } \\
\text { the OSES for } \\
\text { fitting into } \\
\text { different learning } \\
\text { mode. }\end{array}$ \\
\hline
\end{tabular}

Remarks:

$\mathrm{Cl}=$ Confidence Interval

$\mathrm{I}-\mathrm{CVI}=$ Item-level Content Validity Index

S-CVI/AVE = Scale-level Content Validity Index

※ Previous studies were based on the Li and Yu (2015).

* The result is calculated based on 70 nursing students.

\# The result is calculated based on 20 nursing students only. 


\begin{tabular}{|c|c|c|c|}
\hline & $\begin{array}{l}\text { Original DSES } \\
\text { items } \\
\text { (presented in } \\
\text { both English } \\
\text { and Simplified } \\
\text { Chinese) }\end{array}$ & $\begin{array}{l}\text { Revised to } \\
\text { GESE items } \\
\text { (presented in } \\
\text { both English } \\
\text { and } \\
\text { Traditional } \\
\text { Chinese) }\end{array}$ & Justifications \\
\hline 29. & 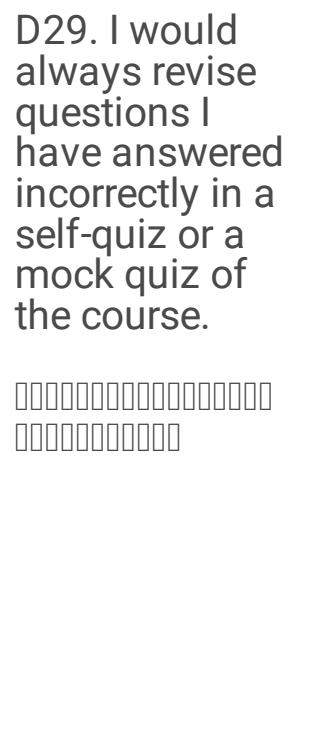 & 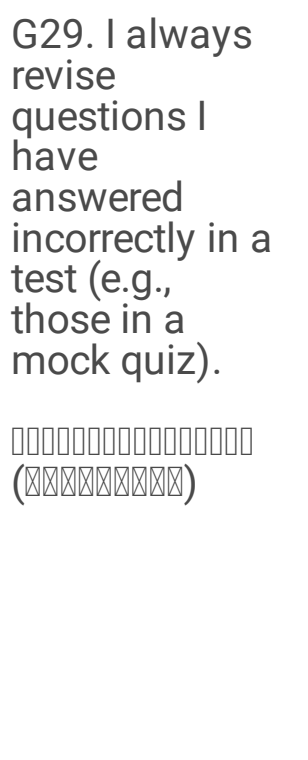 & $\begin{array}{l}\text { Step 1: } \\
\text { Deletion of } \\
\text { "would" was } \\
\text { performed to } \\
\text { increase the } \\
\text { comprehensibility } \\
\text { in Cantonese. } \\
\text { Examples were } \\
\text { added in blanket } \\
\text { to increase the } \\
\text { relevance and } \\
\text { adaptability of } \\
\text { the OSES for } \\
\text { fitting into } \\
\text { different learning } \\
\text { mode. }\end{array}$ \\
\hline 30. & 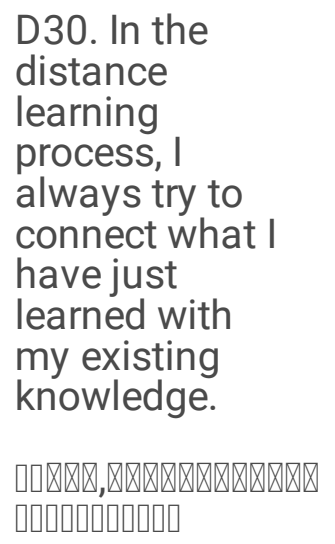 & 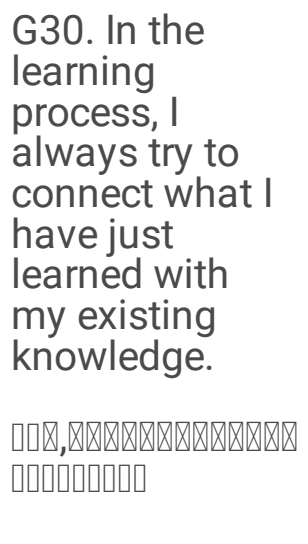 & $\begin{array}{l}\text { Step 1: } \\
\text { The emphasis of } \\
\text { distance learning } \\
\text { mode was } \\
\text { removed. }\end{array}$ \\
\hline
\end{tabular}

\section{Remarks:}

$\mathrm{Cl}=$ Confidence Interval

$\mathrm{I}-\mathrm{CVI}=$ Item-level Content Validity Index

S-CVI/AVE = Scale-level Content Validity Index

※ Previous studies were based on the Li and Yu (2015).

* The result is calculated based on 70 nursing students.

\# The result is calculated based on 20 nursing students only. 


\begin{tabular}{|c|c|c|c|}
\hline & $\begin{array}{l}\text { Original DSES } \\
\text { items } \\
\text { (presented in } \\
\text { both English } \\
\text { and Simplified } \\
\text { Chinese) }\end{array}$ & $\begin{array}{l}\text { Revised to } \\
\text { GESE items } \\
\text { (presented in } \\
\text { both English } \\
\text { and } \\
\text { Traditional } \\
\text { Chinese) }\end{array}$ & Justifications \\
\hline 31. & 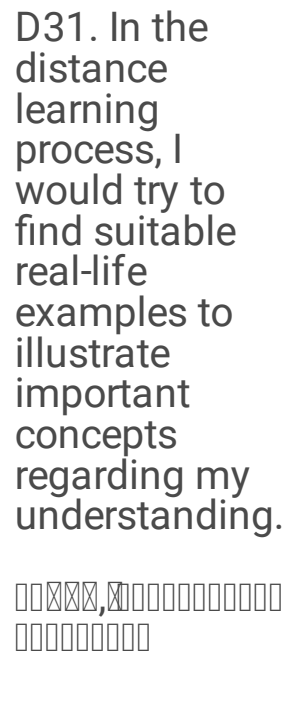 & 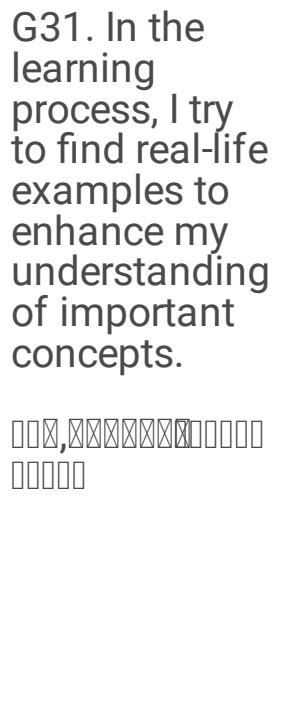 & $\begin{array}{l}\text { Step 1: } \\
\text { Deletion of } \\
\text { "would" was } \\
\text { performed to } \\
\text { increase the } \\
\text { comprehensibility } \\
\text { in Cantonese. } \\
\text { The emphasis of } \\
\text { distance learning } \\
\text { mode was } \\
\text { removed. } \\
\text { Item was } \\
\text { shortened to } \\
\text { increase clarity. }\end{array}$ \\
\hline 32. & 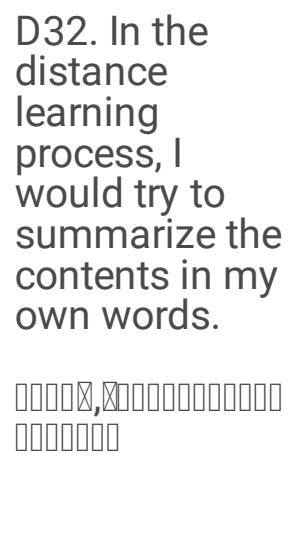 & 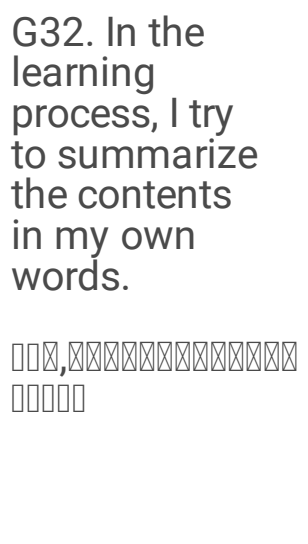 & $\begin{array}{l}\text { Step 1: } \\
\text { Deletion of } \\
\text { "would" was } \\
\text { performed to } \\
\text { increase the } \\
\text { comprehensibility } \\
\text { in Cantonese. } \\
\text { The emphasis of } \\
\text { distance learning } \\
\text { mode was } \\
\text { removed. }\end{array}$ \\
\hline
\end{tabular}

\section{Remarks:}

$\mathrm{Cl}=$ Confidence Interval

$\mathrm{I}-\mathrm{CVI}=$ Item-level Content Validity Index

S-CVI/AVE = Scale-level Content Validity Index

※ Previous studies were based on the Li and Yu (2015).

* The result is calculated based on 70 nursing students.

\# The result is calculated based on 20 nursing students only. 


\begin{tabular}{|c|c|c|c|}
\hline & $\begin{array}{l}\text { Original DSES } \\
\text { items } \\
\text { (presented in } \\
\text { both English } \\
\text { and Simplified } \\
\text { Chinese) }\end{array}$ & $\begin{array}{l}\text { Revised to } \\
\text { GESE items } \\
\text { (presented in } \\
\text { both English } \\
\text { and } \\
\text { Traditional } \\
\text { Chinese) }\end{array}$ & Justifications \\
\hline \multirow[t]{3}{*}{33.} & $\begin{array}{l}\text { D33. I would } \\
\text { try to arrange } \\
\text { for a rather } \\
\text { comfortable } \\
\text { environment } \\
\text { for my } \\
\text { distance } \\
\text { learning. }\end{array}$ & \multirow[t]{3}{*}{ 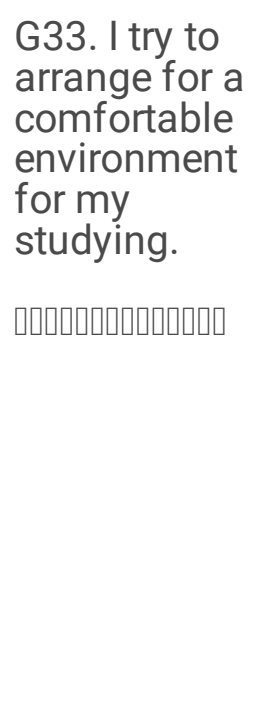 } & $\begin{array}{l}\text { Step 1: } \\
\text { Deletion of } \\
\text { "would" was } \\
\text { performed to } \\
\text { increase the } \\
\text { comprehensibility } \\
\text { in Cantonese. }\end{array}$ \\
\hline & \multirow[t]{2}{*}{ 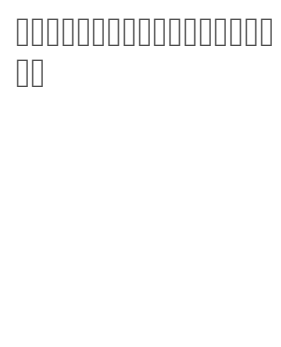 } & & $\begin{array}{l}\text { The emphasis of } \\
\text { distance learning } \\
\text { mode was } \\
\text { removed. }\end{array}$ \\
\hline & & & $\begin{array}{l}\text { Item was } \\
\text { shortened to } \\
\text { increase clarity. }\end{array}$ \\
\hline \multirow[t]{4}{*}{34.} & \multirow{4}{*}{$\begin{array}{l}\text { D34. I can } \\
\text { manage my } \\
\text { study distance } \\
\text { learning time } \\
\text { fairly well. }\end{array}$} & \multirow{4}{*}{ 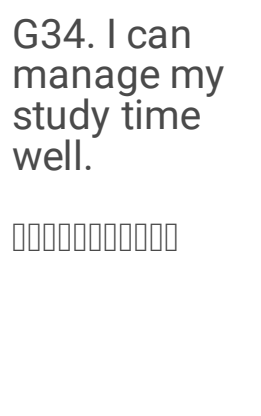 } & Step 1: \\
\hline & & & $\begin{array}{l}\text { The emphasis of } \\
\text { distance learning } \\
\text { mode was }\end{array}$ \\
\hline & & & \\
\hline & & & $\begin{array}{l}\text { Item was } \\
\text { shortened to } \\
\text { increase clarity. }\end{array}$ \\
\hline
\end{tabular}

\section{Remarks:}

$\mathrm{Cl}=$ Confidence Interval

$\mathrm{I}-\mathrm{CVI}=$ Item-level Content Validity Index

S-CVI/AVE = Scale-level Content Validity Index

* Previous studies were based on the Li and Yu (2015).

* The result is calculated based on 70 nursing students.

\# The result is calculated based on 20 nursing students only. 


\begin{tabular}{|c|c|c|c|}
\hline & $\begin{array}{l}\text { Original DSES } \\
\text { items } \\
\text { (presented in } \\
\text { both English } \\
\text { and Simplified } \\
\text { Chinese) }\end{array}$ & $\begin{array}{l}\text { Revised to } \\
\text { GESE items } \\
\text { (presented in } \\
\text { both English } \\
\text { and } \\
\text { Traditional } \\
\text { Chinese) }\end{array}$ & Justifications \\
\hline 35. & 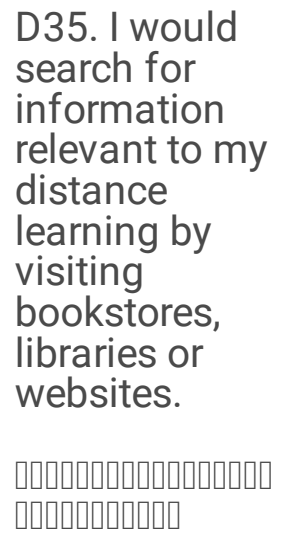 & 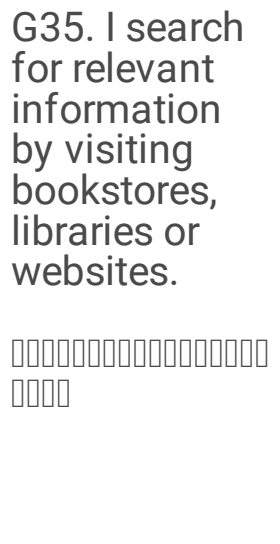 & $\begin{array}{l}\text { Step 1: } \\
\text { Deletion of } \\
\text { "would" was } \\
\text { performed to } \\
\text { increase the } \\
\text { comprehensibility } \\
\text { in Cantonese. }\end{array}$ \\
\hline
\end{tabular}

The emphasis of distance learning mode was removed.

\section{Remarks:}

$\mathrm{Cl}=$ Confidence Interval

$\mathrm{I}-\mathrm{CVI}=$ Item-level Content Validity Index

S-CVI/AVE = Scale-level Content Validity Index

* Previous studies were based on the Li and Yu (2015).

* The result is calculated based on 70 nursing students.

\# The result is calculated based on 20 nursing students only. 


\begin{tabular}{|c|c|c|c|}
\hline & $\begin{array}{l}\text { Original DSES } \\
\text { items } \\
\text { (presented in } \\
\text { both English } \\
\text { and Simplified } \\
\text { Chinese) }\end{array}$ & $\begin{array}{l}\text { Revised to } \\
\text { GESE items } \\
\text { (presented in } \\
\text { both English } \\
\text { and } \\
\text { Traditional } \\
\text { Chinese) }\end{array}$ & Justifications \\
\hline 36. & 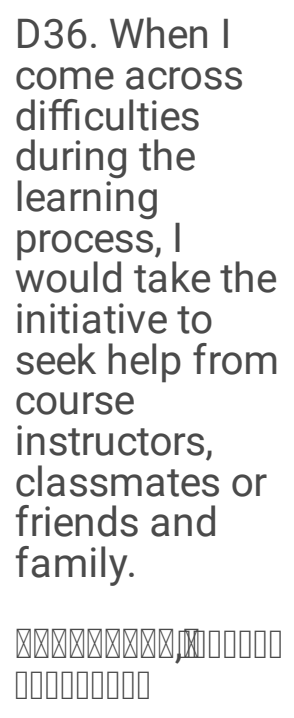 & 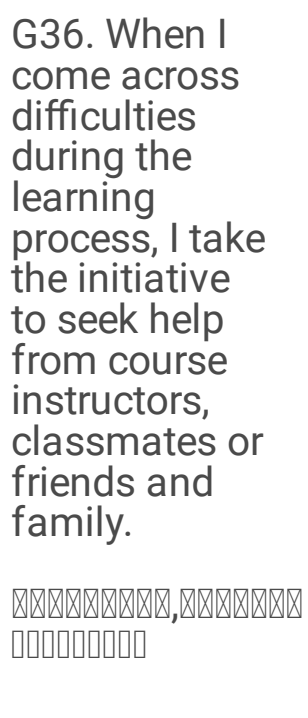 & $\begin{array}{l}\text { Step 1: } \\
\text { Deletion of } \\
\text { "would" was } \\
\text { performed to } \\
\text { increase the } \\
\text { comprehensibility } \\
\text { in Cantonese. }\end{array}$ \\
\hline 37. & $\begin{array}{l}\text { D37. When I } \\
\text { feel a bit low } \\
\text { emotionally } \\
\text { during the } \\
\text { learning } \\
\text { process, I } \\
\text { would look for } \\
\text { ways to help } \\
\text { myself } \\
\text { discover the } \\
\text { fun in learning. } \\
\\
\text { Q } \\
\text { o }\end{array}$ & 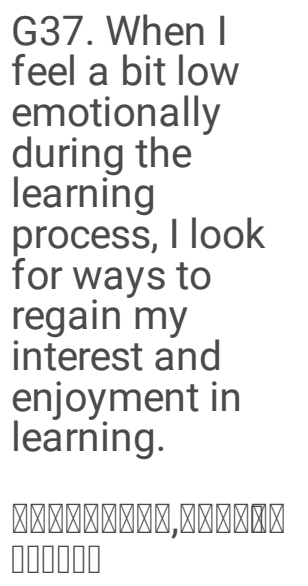 & $\begin{array}{l}\text { Step 1: } \\
\text { Deletion of } \\
\text { "would" was } \\
\text { performed to } \\
\text { increase the } \\
\text { comprehensibility } \\
\text { in Cantonese. } \\
\text { Item was revised } \\
\text { due to the } \\
\text { different Chinese } \\
\text { dialects. }\end{array}$ \\
\hline
\end{tabular}

\section{Remarks:}

$\mathrm{Cl}=$ Confidence Interval

$\mathrm{I}-\mathrm{CVI}=$ Item-level Content Validity Index

S-CVI/AVE = Scale-level Content Validity Index

※ Previous studies were based on the Li and Yu (2015).

* The result is calculated based on 70 nursing students.

\# The result is calculated based on 20 nursing students only. 


\begin{tabular}{|c|c|c|c|}
\hline & $\begin{array}{l}\text { Original DSES } \\
\text { items } \\
\text { (presented in } \\
\text { both English } \\
\text { and Simplified } \\
\text { Chinese) }\end{array}$ & $\begin{array}{l}\text { Revised to } \\
\text { GESE items } \\
\text { (presented in } \\
\text { both English } \\
\text { and } \\
\text { Traditional } \\
\text { Chinese) }\end{array}$ & Justifications \\
\hline 38. & 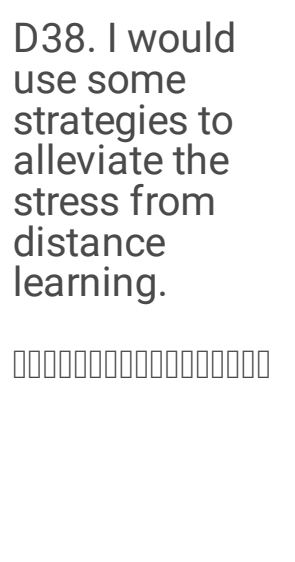 & 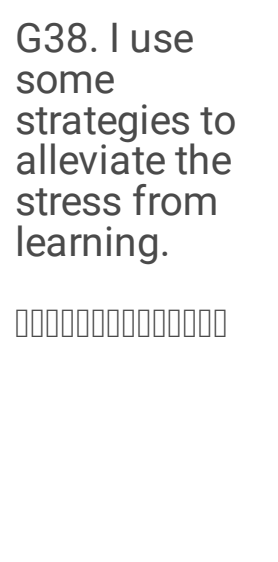 & $\begin{array}{l}\text { Step 1: } \\
\text { Deletion of } \\
\text { "would" was } \\
\text { performed to } \\
\text { increase the } \\
\text { comprehensibility } \\
\text { in Cantonese. } \\
\text { The emphasis of } \\
\text { distance learning } \\
\text { mode was } \\
\text { removed. }\end{array}$ \\
\hline 39. & $\begin{array}{l}\text { D39. When I } \\
\text { come across } \\
\text { setbacks in a } \\
\text { learning } \\
\text { process, I } \\
\text { would be able } \\
\text { to find ways to } \\
\text { strengthen my } \\
\text { beliefs and } \\
\text { regain my } \\
\text { confidence. } \\
\\
\text { Q } \\
\text { and }\end{array}$ & 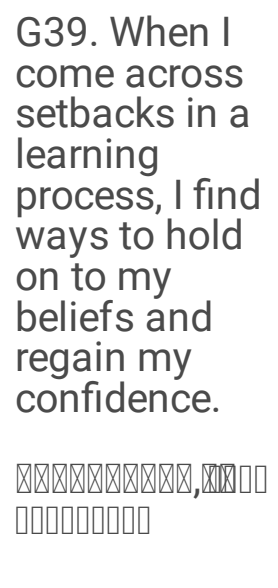 & $\begin{array}{l}\text { Step 1: } \\
\text { Deletion of } \\
\text { "would" was } \\
\text { performed to } \\
\text { increase the } \\
\text { comprehensibility } \\
\text { in Cantonese. }\end{array}$ \\
\hline
\end{tabular}

\section{Remarks:}

$\mathrm{Cl}=$ Confidence Interval

$\mathrm{I}-\mathrm{CVI}=$ Item-level Content Validity Index

S-CVI/AVE = Scale-level Content Validity Index

* Previous studies were based on the Li and Yu (2015).

* The result is calculated based on 70 nursing students.

\# The result is calculated based on 20 nursing students only. 


\begin{tabular}{|c|c|c|c|}
\hline & $\begin{array}{l}\text { Original DSES } \\
\text { items } \\
\text { (presented in } \\
\text { both English } \\
\text { and Simplified } \\
\text { Chinese) }\end{array}$ & $\begin{array}{l}\text { Revised to } \\
\text { GESE items } \\
\text { (presented in } \\
\text { both English } \\
\text { and } \\
\text { Traditional } \\
\text { Chinese) }\end{array}$ & Justifications \\
\hline 40. & $\begin{array}{l}\text { D40. I would } \\
\text { always reflect } \\
\text { on what I have } \\
\text { learned and } \\
\text { how I have } \\
\text { grown during a } \\
\text { learning } \\
\text { process. }\end{array}$ & $\begin{array}{l}\text { G40. I always } \\
\text { reflect on } \\
\text { what I have } \\
\text { learned and } \\
\text { how I have } \\
\text { grown during } \\
\text { a learning } \\
\text { process. }\end{array}$ & $\begin{array}{l}\text { Step 1: } \\
\text { Deletion of } \\
\text { "would" was } \\
\text { performed to } \\
\text { increase the } \\
\text { comprehensibility } \\
\text { in Cantonese. }\end{array}$ \\
\hline
\end{tabular}

\section{Remarks:}

$\mathrm{Cl}=$ Confidence Interval

$\mathrm{I}-\mathrm{CVI}=$ Item-level Content Validity Index

S-CVI/AVE = Scale-level Content Validity Index

* Previous studies were based on the Li and Yu (2015).

* The result is calculated based on 70 nursing students.

\# The result is calculated based on 20 nursing students only. 


\begin{tabular}{|c|c|c|c|}
\hline & $\begin{array}{l}\text { Original DSES } \\
\text { items } \\
\text { (presented in } \\
\text { both English } \\
\text { and Simplified } \\
\text { Chinese) }\end{array}$ & $\begin{array}{l}\text { Revised to } \\
\text { GESE items } \\
\text { (presented in } \\
\text { both English } \\
\text { and } \\
\text { Traditional } \\
\text { Chinese) }\end{array}$ & Justifications \\
\hline 41. & 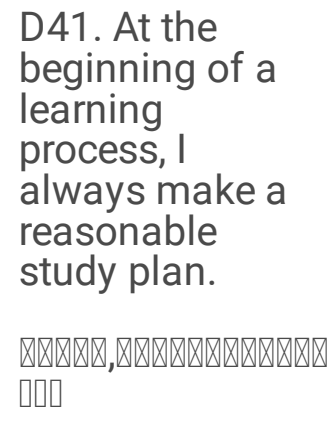 & 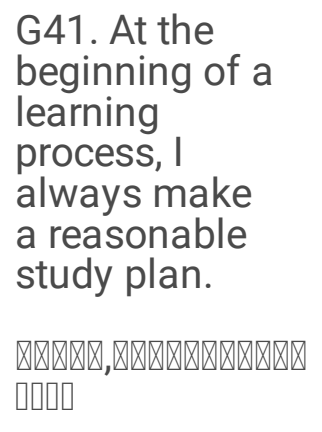 & I \\
\hline 42. & 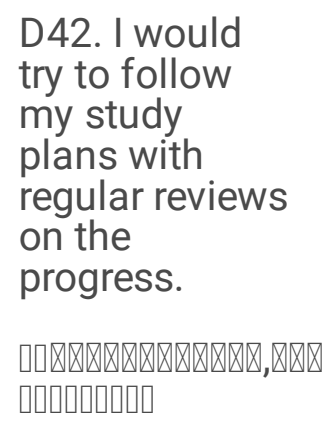 & 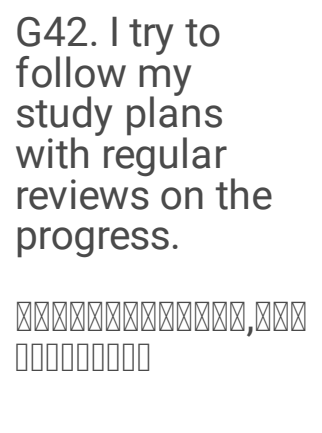 & $\begin{array}{l}\text { Step 1: } \\
\text { Deletion of } \\
\text { "would" was } \\
\text { performed to } \\
\text { increase the } \\
\text { comprehensibility } \\
\text { in Cantonese. }\end{array}$ \\
\hline 43. & 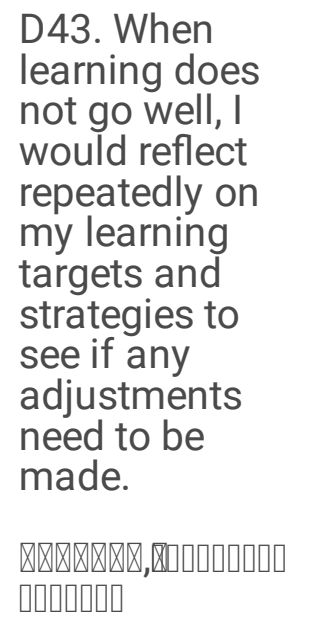 & 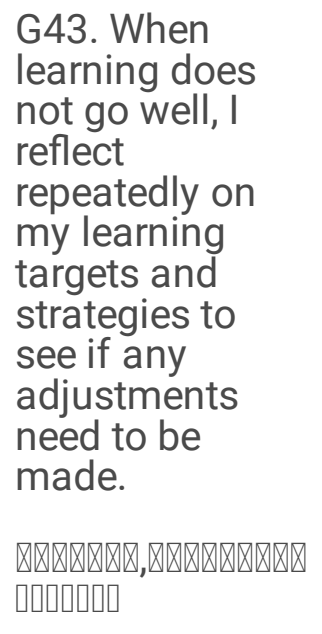 & $\begin{array}{l}\text { Step 1: } \\
\text { Deletion of } \\
\text { "would" was } \\
\text { performed to } \\
\text { increase the } \\
\text { comprehensibility } \\
\text { in Cantonese. }\end{array}$ \\
\hline
\end{tabular}

\section{Remarks:}

$\mathrm{Cl}=$ Confidence Interval

$\mathrm{I}-\mathrm{CVI}=$ Item-level Content Validity Index

S-CVI/AVE = Scale-level Content Validity Index

※ Previous studies were based on the Li and Yu (2015).

* The result is calculated based on 70 nursing students.

\# The result is calculated based on 20 nursing students only. 


\begin{tabular}{|c|c|c|c|c|c|}
\hline & $\begin{array}{l}\text { Original DSES } \\
\text { items } \\
\text { (presented in } \\
\text { both English } \\
\text { and Simplified } \\
\text { Chinese) }\end{array}$ & $\begin{array}{l}\text { Revised to } \\
\text { GESE items } \\
\text { (presented in } \\
\text { both English } \\
\text { and } \\
\text { Traditional } \\
\text { Chinese) }\end{array}$ & Justifications & & \\
\hline 44. & 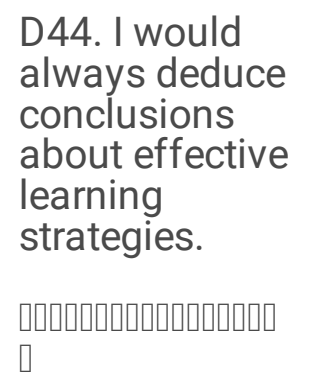 & 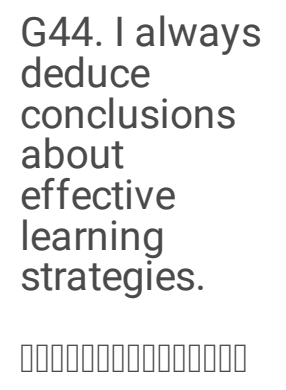 & $\begin{array}{l}\text { Step 1: } \\
\text { Deletion of } \\
\text { "would" was } \\
\text { performed to } \\
\text { increase the } \\
\text { comprehensibility } \\
\text { in Cantonese. }\end{array}$ & & \\
\hline \multirow[t]{4}{*}{45.} & $\begin{array}{l}\text { D45. I would } \\
\text { regularly } \\
\text { review my } \\
\text { learning } \\
\text { outcomes and } \\
\text { diagnose my } \\
\text { learning } \\
\text { problems. }\end{array}$ & $\begin{array}{l}\text { G45. I } \\
\text { regularly } \\
\text { review my } \\
\text { learning } \\
\text { outcomes and } \\
\text { analyze my } \\
\text { learning } \\
\text { problems. }\end{array}$ & $\begin{array}{l}\text { Step 1: } \\
\text { Deletion of } \\
\text { "would" was } \\
\text { performed to } \\
\text { increase the } \\
\text { comprehensibility } \\
\text { in Cantonese. }\end{array}$ & & \\
\hline & 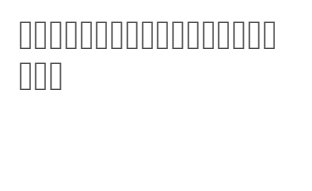 & 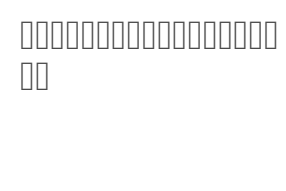 & $\begin{array}{l}\text { Item was revised } \\
\text { due to the } \\
\text { different Chinese } \\
\text { dialects. }\end{array}$ & & \\
\hline & The current stud & & & & $\begin{array}{l}\text { Previous } \\
\text { studies* }\end{array}$ \\
\hline & Methods & & Statistic methods & Results & Results \\
\hline
\end{tabular}

\section{Remarks:}

$\mathrm{Cl}=$ Confidence Interval

$\mathrm{I}-\mathrm{CVI}=$ Item-level Content Validity Index

S-CVI/AVE = Scale-level Content Validity Index

* Previous studies were based on the Li and Yu (2015).

* The result is calculated based on 70 nursing students.

\# The result is calculated based on 20 nursing students only. 


\begin{tabular}{|c|c|c|c|c|c|}
\hline & $\begin{array}{l}\text { Original DSES } \\
\text { items } \\
\text { (presented in } \\
\text { both English } \\
\text { and Simplified } \\
\text { Chinese) }\end{array}$ & $\begin{array}{l}\text { Revised to } \\
\text { GESE items } \\
\text { (presented in } \\
\text { both English } \\
\text { and } \\
\text { Traditional } \\
\text { Chinese) }\end{array}$ & Justifications & & \\
\hline \multirow[t]{2}{*}{$\begin{array}{l}\text { 1. Internal } \\
\text { consistency }\end{array}$} & \multirow{2}{*}{\multicolumn{2}{|c|}{ Cronbach's method }} & $\begin{array}{l}\text { Cronbach's alpha } \\
\text { statistic }\end{array}$ & $\begin{array}{l}\text { Alpha of scale }= \\
0.93\end{array}$ & $\begin{array}{l}\text { Alpha }= \\
0.96\end{array}$ \\
\hline & & & & $\begin{array}{l}\text { Alpha of } \\
\text { subscales }= \\
0.80-0.90\end{array}$ & $\begin{array}{l}\text { Alpha of } \\
\text { subscales } \\
=0.88- \\
0.93\end{array}$ \\
\hline \multirow[t]{2}{*}{ 2. Stability } & \multirow{2}{*}{\multicolumn{2}{|c|}{ 4-week test-retest reliability* }} & \multirow{2}{*}{$\begin{array}{l}\text { Intraclass } \\
\text { correlation } \\
\text { coefficient }\end{array}$} & $r=0.88, p<.001$ & \multirow[t]{2}{*}{ NA } \\
\hline & & & & $\begin{array}{l}95 \% \mathrm{Cl}=0.81- \\
0.92\end{array}$ & \\
\hline \multicolumn{6}{|l|}{ Validity } \\
\hline \multirow[t]{2}{*}{$\begin{array}{l}\text { 1. Face } \\
\text { validity }\end{array}$} & \multirow{2}{*}{$\begin{array}{l}\text { Review by } \\
\text { target } \\
\text { population }{ }^{\#}\end{array}$} & \multirow{2}{*}{\multicolumn{2}{|c|}{ Frequency \& percentage }} & $\begin{array}{l}100 \% \\
\text { comprehensibility }\end{array}$ & NA \\
\hline & & & & $\begin{array}{l}100 \% \\
\text { interpretability }\end{array}$ & \\
\hline \multirow[t]{2}{*}{$\begin{array}{l}\text { 2. Content } \\
\text { validity }\end{array}$} & \multirow[t]{2}{*}{$\begin{array}{l}\text { Review by } \\
\text { expert panel }\end{array}$} & \multirow{2}{*}{\multicolumn{2}{|c|}{ Content validity index }} & $\begin{array}{l}\mathrm{I}-\mathrm{CVI}=0.71-1.00 \\
\text { (except G9) }\end{array}$ & NA \\
\hline & & & & $S-C V I=0.92$ & \\
\hline $\begin{array}{l}3 . \\
\text { Construct } \\
\text { validity }\end{array}$ & $\begin{array}{l}\text { Internal } \\
\text { structure }\end{array}$ & \multicolumn{2}{|c|}{ Confirmatory factor analysis } & $\begin{array}{l}\chi^{2} / \mathrm{df}=4.03, \mathrm{CFI} \\
=0.64, \mathrm{ILI}=0.65, \\
\text { RMSEA }=0.08 .\end{array}$ & $\begin{array}{l}\chi^{2} / \mathrm{df}= \\
2.63, \mathrm{CFI} \\
=0.81, \text { ILI } \\
=0.80 \\
\text { RMSEA < } \\
0.08 .\end{array}$ \\
\hline \multicolumn{6}{|l|}{ Remarks: } \\
\hline \multicolumn{6}{|c|}{$\mathrm{Cl}=$ Confidence Interval } \\
\hline \multicolumn{6}{|c|}{$\mathrm{I}-\mathrm{CVI}=$ Item-level Content Validity Index } \\
\hline \multicolumn{6}{|c|}{ S-CVI/AVE = Scale-level Content Validity Index } \\
\hline \multicolumn{6}{|c|}{ ※ Previous studies were based on the Li and Yu (2015). } \\
\hline \multicolumn{6}{|c|}{ * The result is calculated based on 70 nursing students. } \\
\hline
\end{tabular}


Table 4

Rotated factor matrix of the 26-item GSES.

\begin{tabular}{|c|c|c|c|c|}
\hline & Facto & & & \\
\hline Item stems & 1 & 2 & 3 & 4 \\
\hline \multicolumn{5}{|l|}{ Self-regulated learning $(n=9)$} \\
\hline $\begin{array}{l}\text { G26. When studying the course materials, I always highlight the main } \\
\text { points and difficult parts. }\end{array}$ & .589 & .501 & & \\
\hline $\begin{array}{l}\text { G27. I always prepare and revise the related contents in advance } \\
\text { before attending lessons. }\end{array}$ & .532 & & & \\
\hline G34. I can manage my study time well. & .509 & & & \\
\hline $\begin{array}{l}\text { G35. I search for relevant information by visiting bookstores, libraries } \\
\text { or websites. }\end{array}$ & .530 & & & \\
\hline $\begin{array}{l}\text { G41. At the beginning of a learning process, I always make a } \\
\text { reasonable study plan. }\end{array}$ & .661 & & & \\
\hline $\begin{array}{l}\text { G42. I try to follow my study plans with regular reviews on the } \\
\text { progress. }\end{array}$ & .723 & & & \\
\hline $\begin{array}{l}\text { G43. When learning does not go well, I reflect repeatedly on my } \\
\text { learning targets and strategies to see if any adjustments need to be } \\
\text { made. }\end{array}$ & .642 & & & \\
\hline G44. I always deduce conclusions about effective learning strategies. & .627 & & & \\
\hline $\begin{array}{l}\text { G45. I regularly review my learning outcomes and analyze my } \\
\text { learning problems. }\end{array}$ & .687 & & & \\
\hline \multicolumn{5}{|l|}{ Cognitive strategy use $(n=5)$} \\
\hline $\begin{array}{l}\text { G28. I always make use of memorization strategies to study during } \\
\text { the course and review before exams (e.g., learning by rote, using } \\
\text { images and mind maps). }\end{array}$ & & .660 & & \\
\hline $\begin{array}{l}\text { G30. In the learning process, I always try to connect what I have just } \\
\text { learned with my existing knowledge. }\end{array}$ & & .498 & & \\
\hline $\begin{array}{l}\text { G31. In the learning process, I try to find real-life examples to } \\
\text { enhance my understanding of important concepts. }\end{array}$ & & .571 & & \\
\hline $\begin{array}{l}\text { G32. In the learning process, I try to summarize the contents in my } \\
\text { own words. }\end{array}$ & & .694 & & \\
\hline G38. I use some strategies to alleviate the stress from learning. & & .608 & & \\
\hline \multicolumn{5}{|l|}{ Teacher-student interaction $(n=6)$} \\
\hline G7. I share my views and resources with my teachers or students. & & & .637 & \\
\hline
\end{tabular}

* for negatively worded items 


\section{Factor}

G8. I actively respond to questions and calls for help from teachers .656 or students.

G9. I always discuss extra-curricular matters with my teachers or students.

G10. I always discuss course-related learning matters with my .536 classmates.

G11. I participate actively in group learning activities (e.g., group discussion).

G20. I feel that my teachers or students respect my viewpoints and .414 .498 opinions.

\section{Experienced emotion $(n=6)$}

G13. I always feel curious about the course contents that I'm going to learn.

G14. I always look forward to the upcoming course activities.

G15. I am not too interested in the course contents.*

G16. I feel happy when taking part in learning activities.

G23. I always feel bored by the course contents during the learning process.*

G25. I feel bored while doing the assignments.*

* for negatively worded items

The internal consistency of this 26-item 4-factor GSES was re-examined with satisfactory results (Cronbach's alphas $=0.90$ for the entire scale, 0.85 for factor $1,0.80$ for factor $2,0.77$ for factor 3 and 0.77 for factor 4). The stability, which was re-computed for this 26-item GSES, also obtained satisfactory results (ICC $=0.85,95 \%$ confidence interval $=0.77-0.87$ ). Further details are provided in the supplementary material for the final version of GSES.

\section{Discussion}

Understanding student engagement not only facilitates school completion but also shapes educational reform and evaluation [19]. However, student engagement measurement is a subject to be modified according to the learning environment [13]. The newly developed GSES is a timely response to this emerging and latest need, i.e., online and e-learning during the pandemics.

\section{Issues in instrument development}

A conventional instrument development process involved item generation, item reduction, and psychometric testing $[22,28]$. The present study tried to develop a new engagement scale through adapting the most 
relevant existing scale, DSES. This method combined the steps of item generation and reduction together and had the advantage of saving time and additional work in designing item structure and response modality $[23,24]$. Unlike many published studies for instrument development, this study offers an explicit description and justifications on the process of item generation which will facilitate other researchers in this field to adopt the GSES, perform cross-cultural validation, or conduct psychometric testing in another population $[23,28,29]$.

\section{Issues in psychometric testing}

The results of internal consistency, stability, and hypothesis testing suggested satisfactory evidence to the reliability and validity of 45 -item GSES. Comparing the psychometric testing conducted in this study and in $\mathrm{Li}$ and Yu [19]'s study, two issues are worth discussing. First, several significant psychometric properties such as stability, face validity and content validity were investigated in this study. Such results contributed to the knowledge of engagement measurement. Second, based on the same factor structure of GSES and DSES, the Cronbach's alphas were comparative regarding the scale level (0.93 vs 0.96$)$ and subscale levels (0.80-0.90 vs $0.88-0.93)$. Nevertheless, the results of CFA were of great difference between GSES and DSES. Unlike the satisfactory CFA results of DSES, the originally hypothesized 3-factor structure of GSES did not obtain the support from this robust structure examination. Instead, EFA was used to explore the latent structure of GSES among the students in healthcare disciplines. The results suggested a 26-item 4-factor solution. The different factor structure between GSES and DSES will be discussed in the next section. Although it is believed that the relevance and interpretability of 45-item and 26 -item should make no difference, only the internal consistency and stability of this new structure were re-examined. This calls for a further study to re-examine the factor structure through CFA using a new data set.

\section{Conceptual comparison of 26-item GSES, 45-item DSES, and existing instruments}

When examining the four latent factors, it is observed that the items with similar meaning are grouped into one factor. Table 5 presents the comparison of 26 -items GSES and 45-item DSES. 


\section{4-factor model of OSES: \\ 3-factor model of DSES: \\ Domains \\ Domains and concepts}

Self-regulated learning

G26. When studying the course materials, I always highlight the main points and difficult parts.

Cognitive Memory

engagement

G27. I always prepare and revise the related contents in advance before attending lessons.

Cognitive Memory

G34. I can manage my study time well.

engagement

G35. I search for relevant information by visiting bookstores, libraries or websites.

G41. At the beginning of a learning process, I always make a reasonable study plan.

G42. I try to follow my study plans with regular reviews on the progress.

G43. When learning does not go well, I reflect repeatedly on my learning targets and strategies to see if any adjustments need to be made.

$\begin{array}{ll}\begin{array}{l}\text { Cognitive } \\ \text { engagement }\end{array} & \begin{array}{l}\text { Resource } \\ \text { management }\end{array}\end{array}$

Cognitive Resource engagement management

Cognitive Metacognition engagement

Cognitive engagement

Metacognition

Cognitive Metacognition engagement

G44. I always deduce conclusions about effective learning strategies.

G45. I regularly review my learning outcomes and analyze my learning problems.

Cognitive engagement

Cognitive engagement

Metacognition

Metacognition

Cognitive Memory engagement

during the course and review before exams (e.g., learning by rote, using images and mind maps).

G30. In the learning process, I always try to connect what I have just learned with my existing knowledge.

G31. In the learning process, I try to find real-life examples to enhance my understanding of important concepts.

G32. In the learning process, I try to summarize the contents in my own words.

G38. I use some strategies to alleviate the stress from learning.

G28. I always make use of memorization strategies to study during the course and review before exams (e.g., learning by rote, using images and mind maps).

$\begin{array}{ll}\text { Cognitive } & \text { Elaboration } \\ \text { engagement } & \end{array}$

Cognitive engagement

Cognitive engagement

Cognitive engagement

Cognitive engagement
Resource management

Elaboration

Elaboration

Emotional management 
4-factor model of OSES:

Domains 3-factor model of DSES:

Domains and concepts

G7. I share my views and resources with my teachers or students.

G8. I actively respond to questions and calls for help from teachers or students.

G9. I always discuss extra-curricular matters with my teachers or students.

G10. I always discuss course-related learning matters with my classmates.

G11. I participate actively in group learning activities (e.g., group discussion).

G20. I feel that my teachers or students respect my viewpoints and opinions.
Behavioral Interaction

engagement

Behavioral Interaction
engagement

Behavioral Interaction engagement

Behavioral Interaction engagement

Behavioral Interaction engagement

Emotional Belongings engagement

Experienced emotion

G13. I always feel curious about the course contents that I'm going to learn.

Emotional Curiosity engagement

G14. I always look forward to the upcoming course activities.

Emotional Curiosity engagement

G15. I am not too interested in the course contents.

Emotional Curiosity engagement

G16. I feel happy when taking part in learning activities.

Emotional
engagement

Happiness

G23. I always feel bored by the course contents during the learning process.

Emotional engagement

G25. I feel bored while doing the assignments

Emotional engagement

Boredom

Boredom

The factor "self-regulated learning" encompasses nine items that are entirely originated at cognitive engagement of 3-factor model. More importantly, all items clearly reflect how the students perform selfregulated learning through proper management of time and resources, and self-reflection and selfevaluation, and adaptive learning methods. Like the other engagement scales, self-regulated learning grouped as a single factor (or subscale) is common and comparable to the subscale of "self-efficacy" of Motivation and Engagement Scale-High School [33], and the subscale of "reflective \& integrative learning" of NSSE.

The second factor is "cognitive strategy use" that includes six items that come from cognitive engagement of the original model. This factor covers various study strategies that were cognitively embedded in the learning process (e.g., memorization, connection between old and new knowledge, use of real-life examples, and so on). The literature indicated the concepts being identified as "cognitive strategy use" were frequently 
mentioned in the other engagement scales, for example, subscales of "learning strategy section" in Motivated Strategies for Learning Questionnaire (College version) [34] and that of "learning strategies" and "quantitative reasoning" in NSSE.

The factor "teacher-student interaction" encompasses similar concepts including many occasions of interaction between teacher and students to that of behavioral engagement of the original model. Although one item (G20) is regarded as emotional engagement, the meaning of this item describes the sense of being respected during teacher-students interaction. Sense of being respected, in many occasions, would be considered under social dimension. This factor confined the four aspects of behavioral engagement of original model to a single concept, which might suggest that interaction with people shapes the major component of behavioral engagement among students of healthcare disciplines. Similar to the subscale of "teacher-student relationships" and "peer support for learning" in Student Engagement Instrument [5], that of "participation/interaction engagement" in Student Course Engagement Questionnaire [6], and that of "learning from peers" and "student-faculty interaction" in NSSE, the current identified factor "teacher-student interaction" is well justified.

Last, the factor "experienced emotion" covers the essential emotional engagement experienced throughout the learning process, including curiosity, happiness and boredom. The items of this factor are those in emotional engagement of original model. Indeed, the concept of emotional engagement was frequently mentioned in the literature and recognized as one of essential domains in shaping student engagement measurement [6]. EFA was used to remove the items with low factor loading (i.e., identified as noise regarding concept measurement) and increase the measurement quality.

\section{Limitations and recommendations}

Several limitations were worth discussing. Measurement of student engagement sometimes depends on the student learning environment [14]. Although GSES was developed by modifying the latest engagement scale to ensure the relevance and adequacy in contemporary higher education, it is still uncertain whether the GSES is appropriate to measure student engagement in other cultures and educational settings. Indeed, the 3-factor model of 45-item GSES, which has already been recognized as a well-accepted model for engagement measurement, was challenged when it was applied to students with different healthcare background. Therefore, the psychometric properties of either the 45-item or 26-item GSES should be reexamined in other learning environments. The second is about the comprehensiveness of psychometric testing in this study. For this 26-item 4-factor GSES, the satisfactory reliability was well demonstrated in this study, nevertheless, concurrent validation and construct validation, namely CFA and hypothesis testing, have not yet been performed. By recruiting a new group of participants, further examination on this area should be conducted. Last, the literature recommended that the sample size should reach 300 subjects to be regarded acceptable in CFA [25, 34]. However, a complex model (i.e., item number $\geq 30$; Hair et al., 2010) should be computed with a larger sample size to increase the accuracy of goodness-of-fit indices [25, 34]. Further study may consider conducting CFA on 45-item GSES by increasing the sample size [25].

\section{Conclusions}


Student engagement is important in higher education as well as online mode of learning. This study developed the 26-item GSES by modifying the original 45 -item DSES. EFA identified a new 4-factor model (i.e., self-regulated learning, cognitive strategy use, teacher-student interaction, and experienced emotion) in explaining engagement among students of healthcare disciplines in higher education. The content and face validity of these 26 items have been examined in the process of item generation. Furthermore, the results of internal consistency, stability and factorial validity provided a satisfactory evidence to support the reliability and validity of 26 -item GSES. Despite the limitations as stated above, the current study provides an initial attempt to develop a generic student engagement scale that fits the diverse learning modes in higher education.

\section{Abbreviations}

CFA

confirmatory factor analysis

$\mathrm{CFI}$

comparative fit index

CVI

Content validity index (CVI)

DSES

Distance Student Engagement Scale

EFA

Exploratory factor analysis

GESE

Generic Student Engagement Scale

ICC

Intraclass Correlation Coefficient

IFI

Incremental fit index

KMO

Kaiser-Meyer-Olkin

NSSE

National Survey of Student Engagement

OSE

Online Student Engagement

RMSEA

root mean square error of approximation

\section{Declarations}

\section{Ethics approval and consent to participate}


This study was approved by the Ethical Review Committee regarding Human Research, The Open University of Hong Kong (Ref: HE15Mar2016-URC201601). All participants had given informed consent before completing the questionnaire.

\section{Consent for publication}

Not applicable

\section{Availability of data and materials}

Data used during the study are available from the corresponding author on

reasonable request.

\section{Competing interests}

The authors declare no competing interest.

\section{Funding}

This study was supported by three major funds: School of Science and Technology Research Fund (Ref: ST15/16-4), University Research Centre Unit Fund (Ref: URC2016/01), The Open University of Hong Kong, Hong

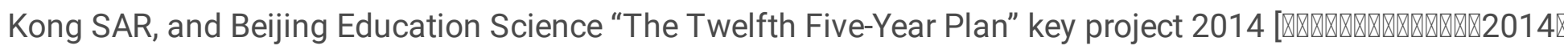
咽因] (Item no.: AJA14180), Beijing Office For Education Science Planning.

\section{Authors' contributions}

SCL, SL, SCNS, JYSC, HCYL, EYMT and KCL conceived the study. SCL SL and SCNS performed data analysis and drafted the manuscript. JYSC HCYL and EYMT collected the data. KCL helped to revise the manuscript. All authors have read and approved the manuscript.

\section{Acknowledgements:}

We thank all participants for their contribution to this study; Ms. Teresa Cheuk Man Yip and Ms. Alice Hau Ting Wong for data collection and data input; Dr. Chloe Chit Ning Li for item translation.

\section{References}

1. McCowan T. Higher education, unbundling, and the end of the university as we know it. Oxford Review of Education. 2017;43(6):733-48. https://doi.org/10.1080/03054985.2017.1343712.

2. Goh PS, Sandars J. A vision of the use of technology in medical education after the COVID-19 pandemic. MedEdPublish 2020;9. https://doi.org/10.15694/mep.2020.000049.1.

3. Basilaia G, Kvavadze D. Transition to online education in schools during a SARS-CoV-2 coronavirus (COVID-19) pandemic in Georgia. Pedagogical Research. 2020;5(4):1-9. https://doi.org/10.29333/pr/7937. 
4. Hew KF. Promoting engagement in online courses: What strategies can we learn from three highly rated MOOCS. Br J Edu Technol. 2016;47(2):320-41. https://doi.org/10.1111/bjet.12235.

5. Appleton JJ, Christenson SL, Furlong MJ. Student engagement with school: Critical conceptual and methodological issues of the construct. Psychol Sch. 2008;45(5):369-86. https://doi.org/10.1002/pits.20303.

6. Handelsman MM, Briggs WL, Sullivan N, Towler A. A measure of college student course engagement. J Educ Res. 2005;98(3):184-92. https://doi.org/10.3200/JOER.98.3.184-192.

7. Guthrie JT, Wigfield A. Engagement and motivation in reading. In: Kamil ML, Mosenthal PB, David Pearson P, Barr R, editors. Handbook of Reading Research. Volume III. London: Taylor \& Francis Group; 2000. pp. 403-22.

8. Christenson SL, Reschly AL, Wylie C, editors. Handbook of Research on Student Engagement. New York: Springer Science \& Business Media; 2012.

9. Kuh GD. What we're learning about student engagement from NSSE: Benchmarks for effective educational practices. Change the Magazine of Higher Learning. 2003;35(2):24-32. https://doi.org/10.1080/00091380309604090.

10. Coates H. Development of the Australasian survey of student engagement (AUSSE). Higher Educ. 2010;60(1):1-17. https://doi.org/10.1007/s10734-009-9281-2.

11. Dixson MD. Measuring student engagement in the online course: The Online Student Engagement scale (OSE). Online Learning. 2015;19(4):n4.

12. Walji S, Deacon A, Small J, Czerniewicz L. Learning through engagement: MOOCs as an emergent form of provision. Distance Education. 2016;37(2):208-23.

https://doi.org/10.1080/01587919.2016.1184400.

13. Fredricks JA, McColskey W. The Measurement of Student Engagement: A Comparative Analysis of Various Methods and Student Self-report Instruments. In: Christenson S, Reschly A, Wylie C, editors. Handbook of Research on Student Engagement. Boston: Springer; 2012. pp. 763-82.

14. Sinatra GM, Heddy BC, Lombardi D. The challenges of defining and measuring student engagement in science. Educ psychol. 2015;50(1):1-13. https://doi.org/10.1080/00461520.2014.1002924.

15. O’Neil CA, Fisher CA, Rietschel MJ. Developing online learning environments in nursing education. 3rd ed. New York: Springer US; 2013.

16. Pimmer C, Brysiewicz P, Linxen S, Walters F, Chipps J, Gröhbiel U. Informal mobile learning in nurse education and practice in remote areas-a case study from rural South Africa. Nurs Educ Today. 2014;34(11):1398-404. https://doi.org/10.1016/j.nedt.2014.03.013.

17. Khalaila R. Simulation in nursing education: An evaluation of students' outcomes at their first clinical practice combined with simulations. Nurs Educ Today. 2014;34(2):252-8. https://doi.org/10.1016/j.nedt.2013.08.015.

18. Fredricks JA, Paris AH. School Engagement: Potential of the concept, state of the evidence. Review of Educ Res. 2004;74(1):59-109. https://doi.org/10.3102/00346543074001059. 
19. Li S, Yu C. Development and implementation of distance students engagement scale. Open Educ Res. 2015;21(6):62-70.

20. Liu TW, Lam SC, Chung MH, Ho KHM. Adaptation and psychometric testing of the hoarding rating scale (HRS): a self-administered screening scale for epidemiological study in Chinese population. BMC Psychiatry. 2020;20:1-10. https://doi.org/10.1186/s12888-020-02539-7.

21. Lam SC. Validation and cross-cultural pilot testing of compliance with standard precautions scale: Selfadministered instrument for clinical nurses. Infect Control Hosp Epidemiol. 2014;35(5):547-55. https://doi.org/10.1086/675835.

22. Streiner DL, Norman GR, Cairney J. Health measurement scales: A practical guide to their development and use. 5th ed. Oxford: Oxford University Press; 2014.

23. Lam C. Development and validation of a quality of life instrument for older Chinese people in residential care homes. Unpublished PhD's thesis. The Chinese University of Hong Kong, Hong Kong. 2015.

24. Mishel MH. Methodological studies: Instrument development. In P. J. Brink, M. J. Wood, editors, Advanced design in nursing research (2nd ed.). Thousand Oaks, California: Saga Publications. 1998; 235-282.

25. Floyd FJ, Widaman KF. Factor analysis in the development and refinement of clinical assessment instruments. Psychol Assess. 1995;7(3):286-99.

26. Lam SC, Chan ZSL, Chong ACY, Wong WWC, Ye J. Adaptation and validation of Richmond Compulsive Buying Scale in Chinese population. J Behav Addict. 2018;7(3):760-9. https://doi.org/10.1556/2006.7.2018.94.

27. Polit DF, Beck CT, Owen SV. Is the CVI an acceptable indicator of content validity? Appraisal and recommendations. Res Nurs Health. 2007;30(4):459-67. https://doi.org/10.1002/nur.20199.

28. Portney L, Watkins G. MP. Foundations of clinical research: Applications to practice. 4th ed. Upper Saddle River: Prentice Hall Health; 2015.

29. Lam SC, Yeung CY, Chan JHM, Lam DWC, Lam AHY, Annesi-Maesano I, et al. Adaptation of the Score for Allergic Rhinitis in Chinese population: Psychometric properties and diagnostic accuracy. Int Arch Allergy Immunol. 2017;173(4):213-24. https://doi.org/10.1159/000477727.

30. Hair JF, Black WC, Babin BJ, Anderson RE. Multivariate Data Analysis. 7th ed. Upper Saddle River: Prentice Hall; 2010.

31. Tabachnick BG, Fidell LS. Using multivariate statistics. Boston: Pearson/Allyn \& Bacon; 2007.

32. Osborne JW, Costello AB, Kellow JT. Best practices in exploratory factor analysis: Four recommendations for getting the most from your analysis. In: Jason Osborne JW, editor. Best Practices in Quantitative Methods. Thousand Oaks: SAGE Publications Inc; 2008. pp. 86-99. https://dx.doi.org/10.4135/9781412995627.d8.

33. Liem GAD, Martin AJ. The Motivation and Engagement Scale: Theoretical framework, psychometric properties, and applied yields. Australian Psychol. 2012;47(1):3-13. https://doi.org/10.1111/j.17429544.2011.00049.x. 
34. Pintrich PR, Smith DAF, GarciaT, McKeachie WJ. Reliability and Predictive Validity of the Motivated Strategies for Learning Questionnaire (MSLQ). Educ Psychol Meas. 1993;53(3):801-13. https://doi.org/10.1177/0013164493053003024.

\section{Supplementary Files}

This is a list of supplementary files associated with this preprint. Click to download.

- SuppIGSESChi.doc

- SuppIGESEEng26.doc 